ARTICLE

Received 20 Feb 2017 | Accepted 11 May 2017 | Published 12 Jul $2017 \quad$ DOl: 10.1057/palcomms.2017.68

\title{
Interiors and interiority in Vermeer: empiricism, subjectivity, modernism
}

\author{
Benjamin Binstock ${ }^{1}$
}

ABSTRACT Johannes Vermeer may well be the foremost painter of interiors and interiority in the history of art, yet we have not necessarily understood his achievement in either domain, or their relation within his complex development. This essay explains how Vermeer based his interiors on rooms in his house and used his family members as models, combining empiricism and subjectivity. Vermeer was exceptionally self-conscious and sophisticated about his artistic task, which we are still laboring to understand and articulate. He eschewed anecdotal narratives and presented his models as models in "studio" settings, in paintings about paintings, or art about art, a form of modernism. In contrast to the prevailing conception in scholarship of Dutch Golden Age paintings as providing didactic or moralizing messages for their pre-modern audiences, we glimpse in Vermeer's paintings an anticipation of our own modern understanding of art. This article is published as part of a collection on interiorities.

\footnotetext{
${ }^{1}$ School of History and Social Sciences, Cooper Union, New York, NY, USA Correspondence: (e-mail: bbinstock@gmail.com)
} 
'All the beautifully furnished rooms, carefully designed interiors, everything so controlled; There wasn't any room for any real feelings between any of us'. - Joey in Woody Allen's Interiors

\section{Woody Allen and Vermeer}

$\mathrm{n}$ the dramatic dénoument of Interiors (1978), Woody Allen's first "serious" film, Joey (Mary Beth Hurt), the miserable daughter of an interior decorator (Geraldine Page), articulates her family's dysfunction in the phrase cited here as epigraph: the beautiful ("high") interiors left no room for ("low") interiority. ${ }^{1}$ The confession corresponds to what André Gide first called mise en abyme, a work of art that contains itself in miniature and reflects upon the artist's means and vision (Gide, 1956: 17). Joey's phrase repeats the title of Allen's film, and distills its essence as a story about unhappy, empty characters in elegant settings. Allen's gesture reflects his artistic self-consciousness, yet also signals a problem with Interiors as an attempt to emulate "high" or "art" film (that is, Ingmar Bergman), which many considered unsuccessful or pompous. Interiors further prefigures a tendency in Allen's later films to compensate waning profundity in content through formal and technical means, presenting A-list ensembles in fantastically expansive and luxurious Manhattan apartments, referred to by some as "real estate porn."2 Allen's true seriousness as a film-maker is thought to reside instead in his "low" comedic films like Annie Hall (1977) and Manhattan (1979), which draw on elements of his life and work, and star his lover as muse (Diane Keaton, also in Interiors), following the precedent of numerous artists and film-makers. ${ }^{3}$

Interiors also raises fascinating questions for its distant ancestors among Johannes Vermeer's paintings (Fig. 1; JV14). ${ }^{4}$ Vermeer may well be the foremost painter of interiors and interiority in the history of art, yet we have not necessarily understood his achievement in either domain, or their relation within his complex development. This essay explains how Vermeer based his interiors on rooms in his house and his figures on family members as models, combining empiricism and subjectivity. Like Allen and many other artists, including Rembrandt, Vermeer drew on his own circumstances in his work, which is partly why his paintings are so compelling for us. He specifically eschewed anecdotal narratives and presented his models as models within "studio" settings, in paintings about paintings, or art about art, a form of modernism.

An artist's oeuvre or body of work is a construct of the modern discipline of art history invented in the nineteenth century, when Vermeer was first recognized as an unknown genius. Yet Vermeer's paintings existed before they were grouped together and represented or recognized for their significance and he was also acutely self-conscious about these issues, more than we have understood. Because most of his small number of paintings, were easily accessible to him in the nearby house of his patron Pieter van Ruijven (see Supplementary Appendix B) (Montias, 1989: 246-62), Vermeer's reflection on his work (oeuvre) may have reached an apex of self-consciousness in the history of art. In contrast to the prevailing conception in scholarship of Dutch Golden Age paintings providing didactic or moralizing messages for their pre-modern audiences, we glimpse in Vermeer's paintings an anticipation of our own modern understanding of art.

\section{Vermeer's interiors and interiority}

Several scholars have proposed that Vermeer's interiors were based on empirical observation of rooms in his house, which they even sought to reconstruct, citing his Music Lesson in particular (Fig. 1), yet they did not pursue the issue in a systematic way and assumed that Vermeer always depicted exactly what was before him ("strict empiricism"). 5 Others denied that he based his scenes on his surroundings, and approached his compositions as imaginative inventions, "rooms he had never seen"
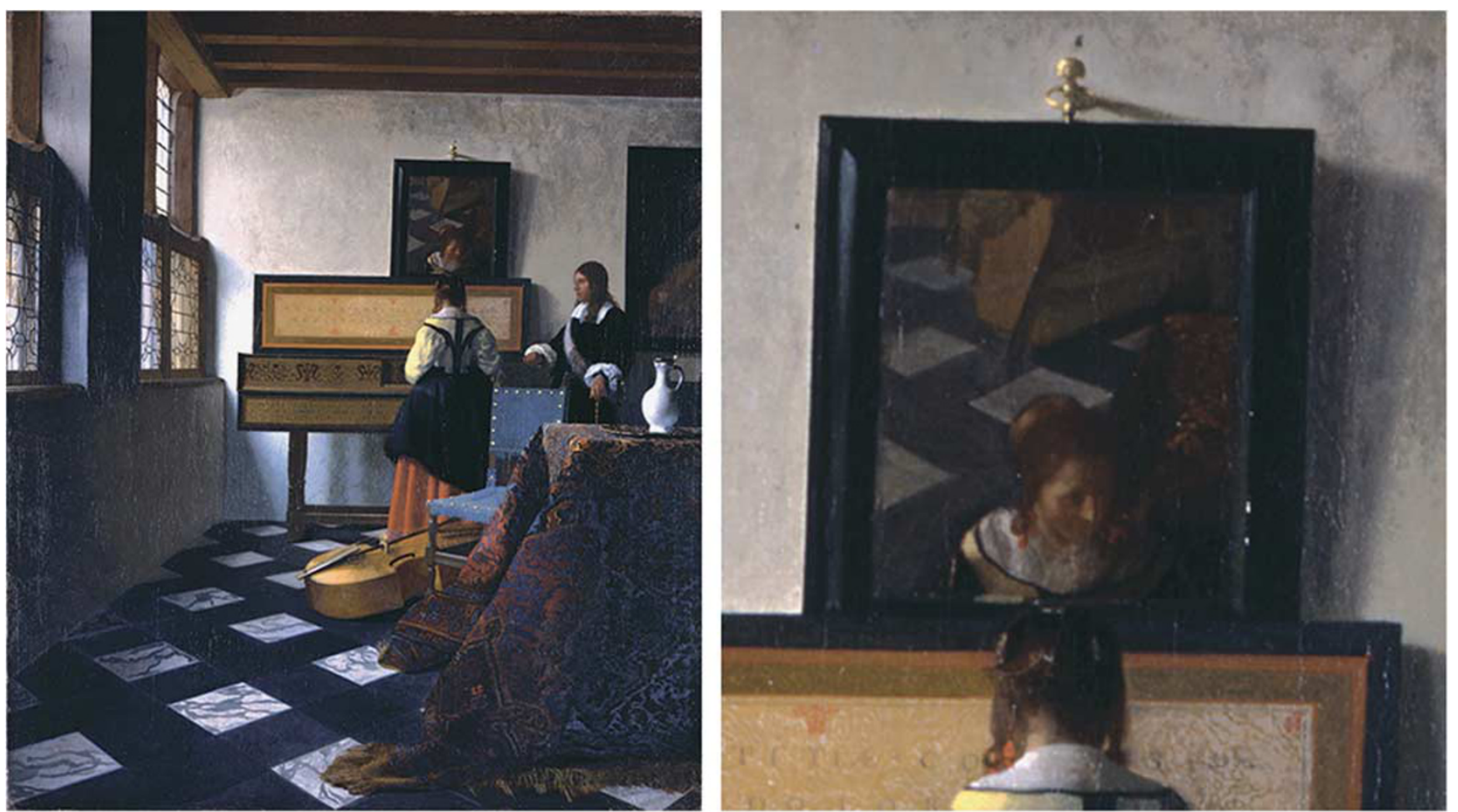

Figure 1 | Johannes Vermeer, Music Lesson, ca. 1662, London, Royal Collection (JV14). 1a. Detail of mirror reflection. Copyright: Royal Collection. This image is reproduced for the purposes of academic review (fair use). It is not covered by a CC-BY 4.0 license. 
(Liedtke, 2008: 105). These debates are bound up with claims that the painter depicted exactly what he observed through a camera obscura, a forerunner of the modern photographic camera (Steadman, 2001: 4-58), or conversely denials that he used a camera at all (Liedtke, 2008: 57), whereas still others proposed that Vermeer deliberately adapted the visual information and optical effects he observed in a camera in his compositions (Gowing, 1952: 23-4, 38, 125).

Scholars also have conflicting views about Vermeer's approach to his figures. Some identified his family members as his models, yet did not pursue the issue in a systematic way (Malraux, 1951), whereas others denied that he used models at all on equally unsystematic grounds (Liedtke, 2008: 102). Vermeer's wife understandably served most often as his model, already recognizable in some of his earliest history paintings (JV2-4) and increasingly explicitly in interiors from throughout the first half of his career. To cite the most obvious examples, his Letter Reader of around 1657 and Woman in Blue from about six years later deliberately show his wife as model in the same activity, pose and profile, visibly pregnant in the latter example (Figs. 2, 2a, 3 and $3 a)$. As a result of reluctance to address this issue, accounts of Vermeer's figures have been limited to subjective guesses about their relations and what they might be feeling, or projections concerning our feelings about them or his feelings about humanity and "the feminine" (Gowing, 1952: 25, 26, 34, 101 and Liedtke, 2008). The wealth of information about Vermeer's family uncovered by J.M. Montias has not been brought to bear on Vermeer's paintings, whereas his use of rooms and models have not been not related to one another.

My 2009 book Vermeer's Family Secrets sought to explain how Vermeer self-consciously based all his interiors on rooms in his house and all his figures on family members as models, dimensions he adapted in a "subjective empiricism." His Little
Street (Fig. 4; JV17) depicts his (long since destroyed) home at de Oude Langendijk 27 in Delft on the right: the number and types of panes in the windows match those in his three most common types of his interiors (Fig. 5) (Binstock, 2009: 7-16). ${ }^{6}$ Vermeer's Music Lesson, his most ambitious interior and the room that the "strict empiricists" repeatedly sought to reconstruct in various ways, was based on the eastern (left) ground floor "front hall" [ het voorhuys] of his house (Figs. 1, 4 and 5), yet he doubled its windows and size to make the interior appear extraordinarily large and luxurious. Around his house are his family members: his wife sewing in the threshold and his maid cleaning in the alley, in the same or similar clothes they wear as models in his other paintings, and what was presumably his eldest daughter playing on the front stoop beside a boy companion.

Vermeer scholars have not yet addressed these proposals, which conflict with their own generally consistent conception of what constitutes historical evidence and meaning in Golden Age paintings. ${ }^{7}$ As regards historical evidence, we have no written documents asserting that Vermeer did or did not use the rooms in his house as the basis for his interiors or his family members as models, yet also no reason to expect such documents. Fortunately, the paintings are visual historical documents and our task as historians of art, or as the Germans would say Kunstwissenschaftler [practitioners of the scientific study of art], is to evaluate this evidence as thoroughly and systematically as possible. The primary evidence involves paintings assigned to Vermeer (Supplementary Appendix A) and secondarily paintings by his contemporaries such as Rembrandt (Figs. 6 and 7). Written documents are equally important (Supplementary Appendix B), yet their significance in relation to Vermeer's paintings has largely been overlooked. A synthesis of pictorial and written documents is needed, connecting the dots of the historical evidence or filling in what has been left as ellipses in earlier scholarship.
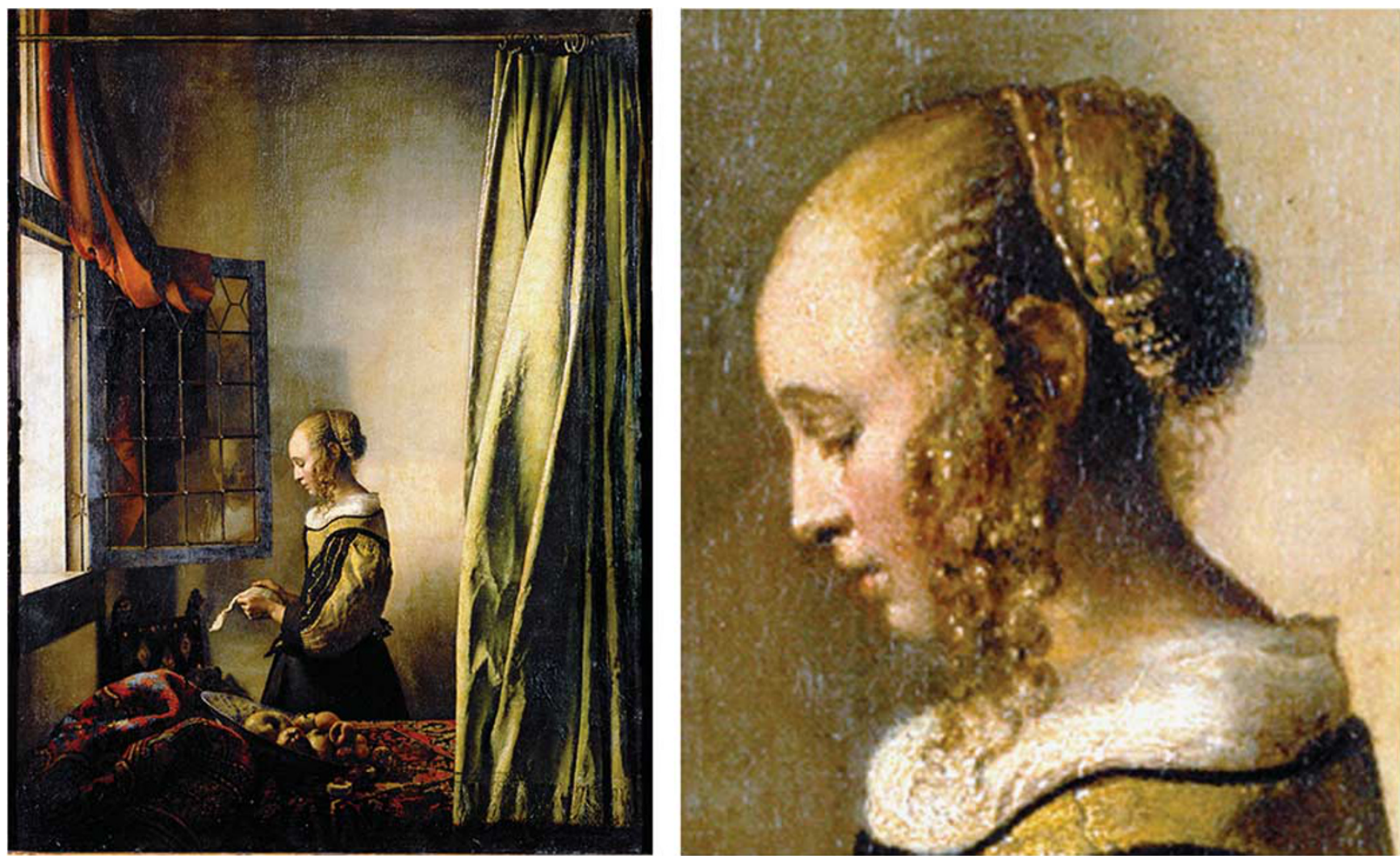

Figure 2 | Vermeer, Letter Reader, ca. 1657, Dresden, Gemäldegalerie (JV7). 2a. Detail of model's face: Catharina Bolnes? Copyright: Dresden Gemäldegalerie. This image is reproduced for the purposes of academic review (fair use). It is not covered by a CC-BY 4.0 license. 

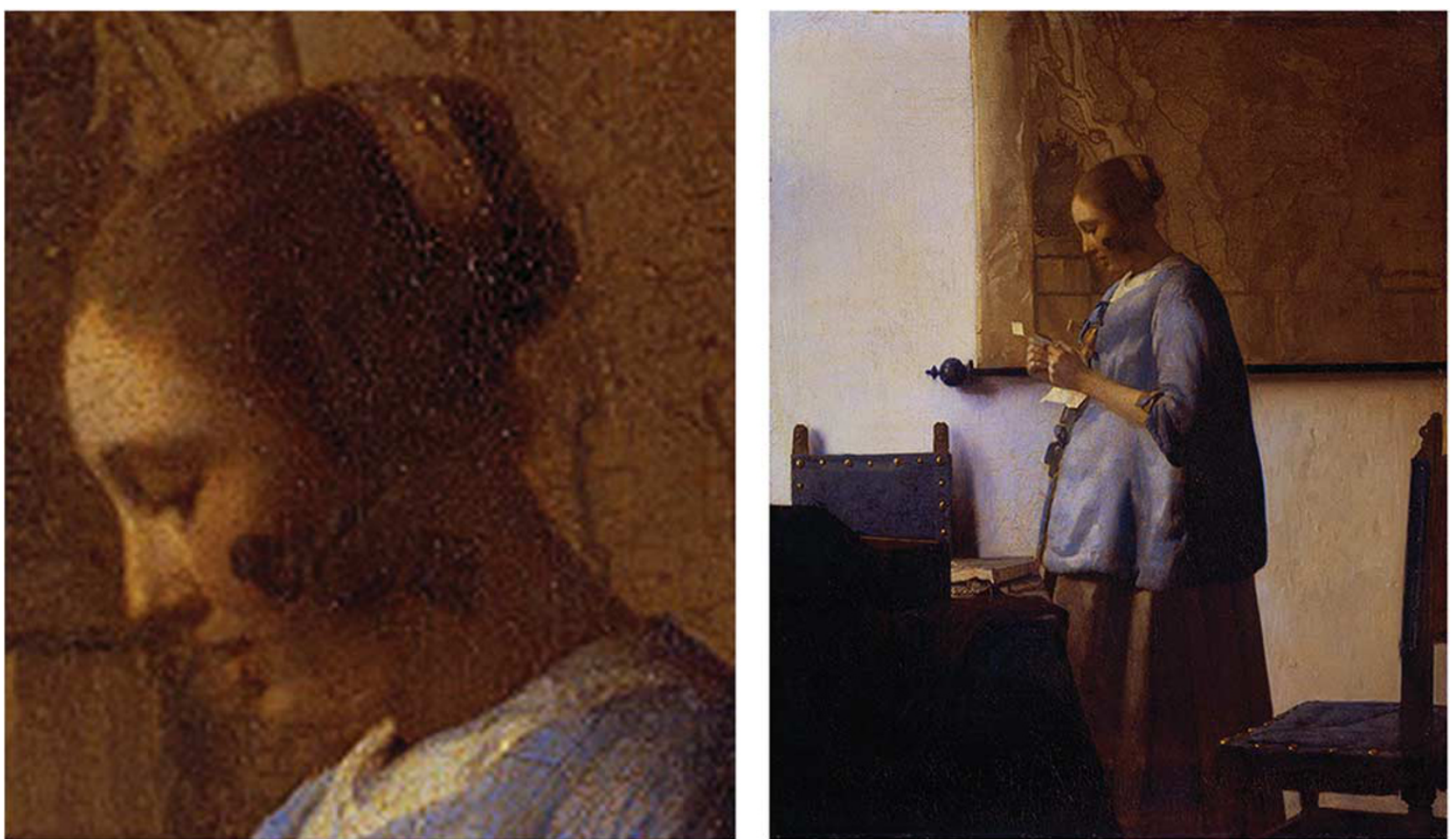

Figure 3 | Vermeer, Woman in Blue, ca. 1663, Amsterdam, Rijksmuseum (JV16). 3a. Detail of model's face: Catharina Bolnes? Copyright: Rijksmuseum. This image is reproduced for the purposes of academic review (fair use). It is not covered by a CC-BY 4.0 license.

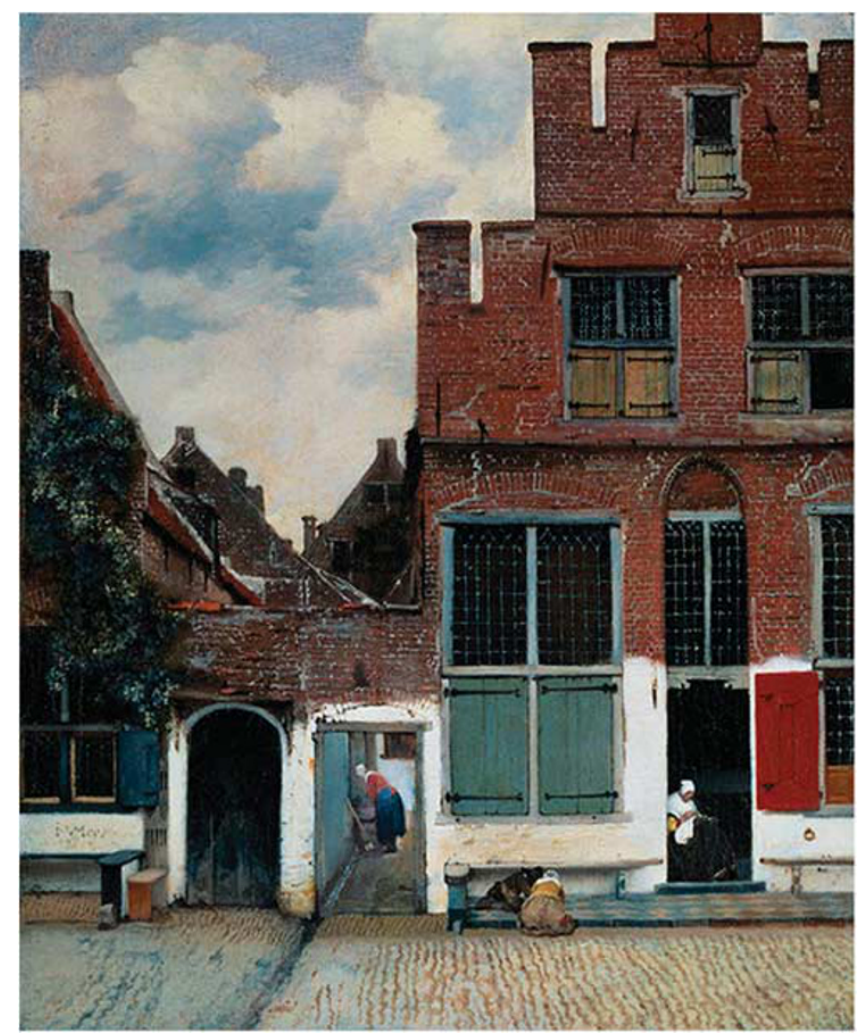

Figure 4 | Vermeer, The Little Street, ca. 1664, Amsterdam, Rijksmuseum (JV17). Copyright: Rijksmuseum. This image is reproduced for the purposes of academic review (fair use). It is not covered by a CC-BY 4.0 license.
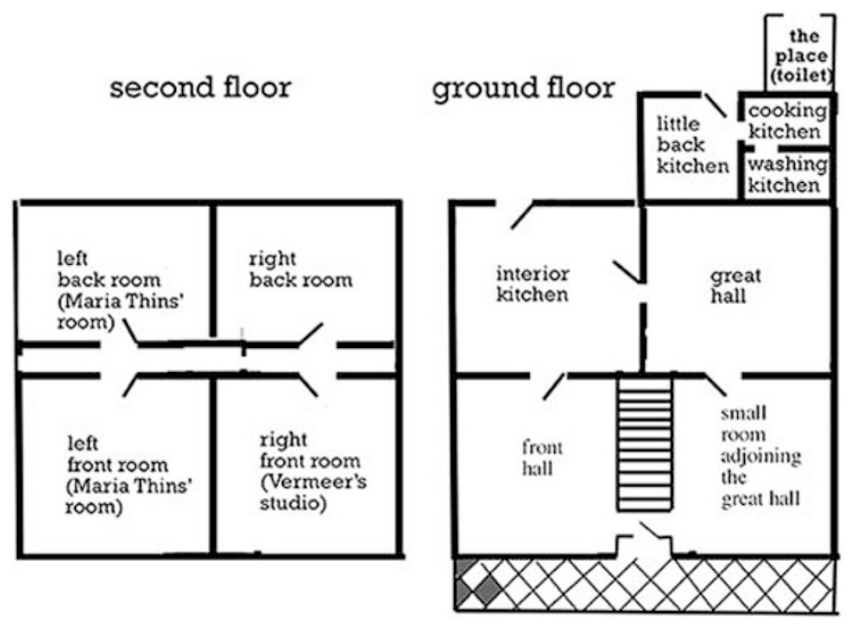

Figure 5 | Schematic ground plan of the rooms in Vermeer's house.

As regards meaning in Golden Age paintings, many scholars seek to discover messages for a patron or other historical audience. However, Vermeer's contemporaries had little or nothing to say about his paintings and their articulated views of art were rudimentary. Alternatively, the meanings of Vermeer's paintings can be seen to derive primarily from his creative act, a process we can sometimes follow in surprising depth and over time, extending to his broader development and body of work.

My emphasis on Vermeer's family members as models is easily misunderstood as an "anachronistic" Romantic view of his art as illustrating his life (Grijzenhout, 2015: 23). Yet Vermeer did not depict scenes from his own life. Rather, he based his interiors on rooms in his house and used family members as models, or in 


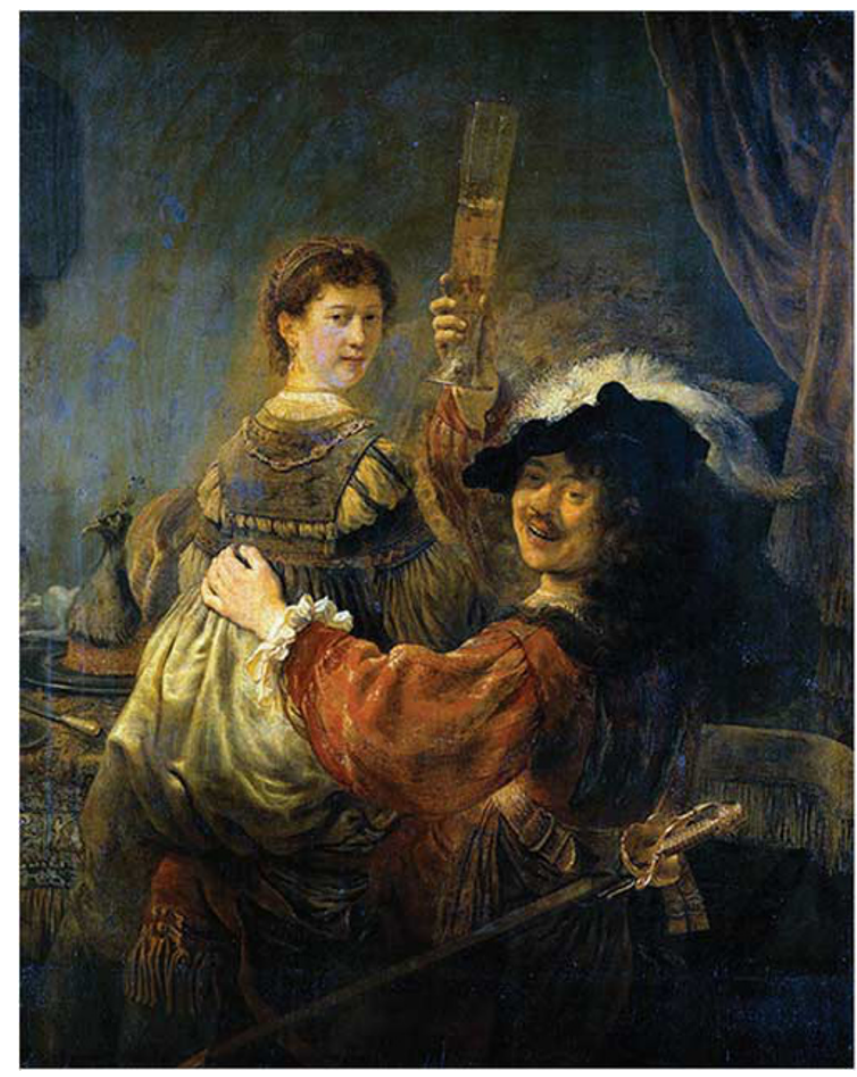

Figure 6 | Rembrandt, Prodigal Son in the Tavern, ca. 1638, Amsterdam, Rijksmuseum. Copyright: Rijksmuseum. This image is reproduced for the purposes of academic review (fair use). It is not covered by a CC-BY 4.0 license.

paintings like his Little Street depicted his own surroundings (his house), a "pre-Romantic" paradigm. The charge of anachronism needs to be reversed insofar as many French nineteenth-century (Romantic) "painters of modern life" were directly inspired by Dutch Golden Age genre paintings. Vincent van Gogh in particular intuited Vermeer's self-reflexive subjects when he named his painting of his own house The Yellow House, The Street after Vermeer's precedent and called attention in one of his letters to "a very beautiful pregnant Dutch lady" in Vermeer's Woman in Blue (van Gogh, 1978: 503-504).

One must further distinguish among diverse categories [genres], the term first employed by eighteenth-century French writers to designate Dutch still lives, landscapes, portraits and scenes of figures in interiors or outdoors. Most portraits and landscapes depict exactly what one would have seen, whereas still lives were usually artificially composed, albeit carefully observed, and scenes of figures in interiors encompass a wide range of approaches. We must also differentiate among diverse painters. Perhaps the most gifted and certainly the most self-conscious genre painter, coming near the end of his tradition, Vermeer distilled its essence in its purest form. By eschewing anecdotal narratives of the type depicted by his peers, and focusing instead on his family members as models in the rooms of his house as an extension of his studio, Vermeer emphasized rigorous observation and naturalism in the manner of portraiture and landscape, in what might be called "human still lives."

Vermeer's idiosyncratically straightforward approach to his studio models culminated a strain of radical naturalism begun by Caravaggio, evident in Velázquez and Hals, and advanced by Rembrandt. Vermeer's self-consciousness about his creative

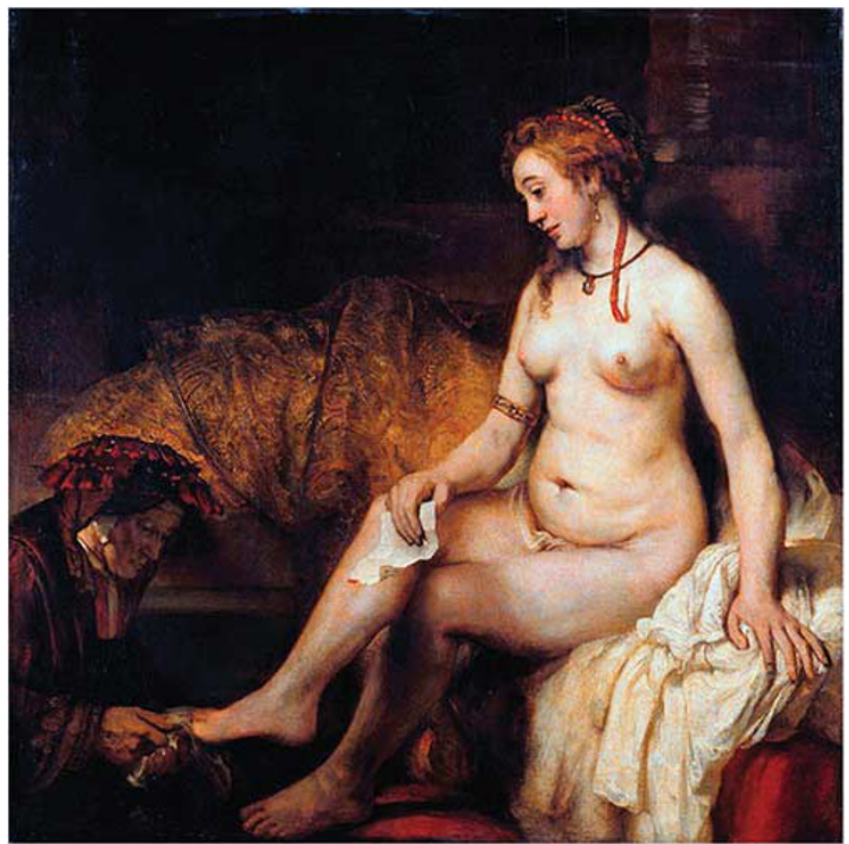

Figure 7 | Rembrandt, Bathsheba, 1654, Paris, Louvre. Copyright: Louvre. This image is reproduced for the purposes of academic review (fair use). It is not covered by a CC-BY 4.0 license.

process further anticipated the strategies of French Modernist paintings such as Edouard Manet's Street Singer and Olympia based on his model Victorine Meurent. ${ }^{8}$ Vermeer's rigorous yet poetic naturalism, his convincing interiors and his figures' compelling interiority, is what makes him the foremost genre painter and one of the most beloved painters in the history of art. Yet these distinctions were not acknowledged in his time and remain only partly understood. Vermeer's reflection on the concrete conditions of his artistic production constitutes his still unrecognized, primary contribution as an artist.

\section{The modernism of Vermeer's procuress}

All scholars recognize Vermeer's Procuress of 1656 (Fig. 8) as a crucial transition from his earliest history paintings to genre paintings, and identify his primary pictorial source as Dirk van Baburen's Procuress (Fig. 9), which Vermeer's mother-in-law owned (Montias, 1989: 122). ${ }^{9}$ Baburen shows picturesque types of the carefree whore and the old crone in a turban as female pimp or procuress; the traditional Dutch title "coupler" [koppelaarster] is more concretely evocative. Baburen likely used himself as model for the client (or Prodigal Son in the Tavern) with his distinctive features and goatee, as seen in a contemporary portrait drawing, dressed in the traditional Germanic striped jacket and beret adopted in Netherlandish self-portraits in the guise of the Prodigal Son (Binstock, 2009: 78-79). One of a group of followers of Caravaggio, the so-called Utrecht caravaggisti, the first modern school of Dutch painting, Baburen took up self-portraiture, a core of modernism, as a means to relate to his contemporary environment.

Other scholars recognized a second source for Vermeer in Rembrandt's Prodigal Son in the Tavern (Fig. 6), for which he used himself and his wife Saskia as models (Bürger, 1866: 559). Rembrandt greatly expanded on self-portraiture, using family members as models and drawing on his own circumstances, making himself the center of his art. His in-laws accused him (with good reason) of squandering Saskia's inheritance, and he 


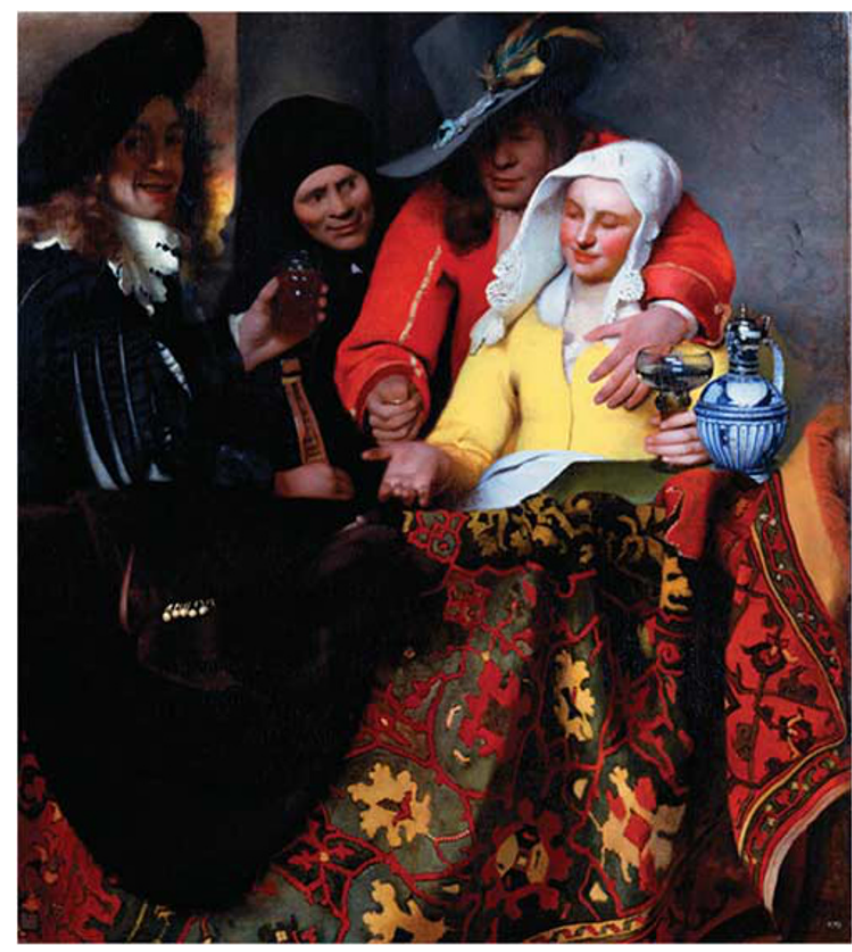

Figure 8 | Vermeer, Procuress, 1656, Dresden, Gemäldegalerie (JV5). Copyright: Dresden Gemäldegalerie. This image is reproduced for the purposes of academic review (fair use). It is not covered by a CC-BY 4.0 license.

sued them for libel (Strauss and van der Meulen, 1979: 152-5). In his painting he assumed the role of the profligate Prodigal Son traditionally used in painters' self-portraits, and employed his wife as model for the harlot, a role he portrayed her indulgently accepting. He thereby underscored their affectionate relations, challenged his in-laws and created a lively scene.

Vermeer elaborated on and synthesized elements of Baburen and Rembrandt's strategies. Most scholars recognize Vermeer's self-portrait in the musician at the left, toasting the others (and us), dressed in the traditional slashed jacket and beret in Netherlandish painters' self-portraits as the Prodigal Son. Some identified Vermeer's wife Catharina as model for the prostitute in yellow on the right and "family members" between them, or Vermeer's mother-in-law Maria Thins as model for the procuress in particular (Goldschieder, 1958: 23). This was an appropriate role since she "coupled" Vermeer and Catherina though her consent to their marriage, and is shown in what looks like a black nun's habit signalling her devout Catholicism. Scholars also observed that Vermeer holds the neck of his musical instrument as if miming masturbation, yet never explained the purpose of this gesture or the function of Vermeer and his family members within the brothel scene (Liedtke, 2008: 64).

A missing piece of the puzzle involves the unidentified model for the soldier-client. This was logically the remaining adult member of Vermeer's adopted household, his brother-in-law Willem, who owned a (red) "coloured mantel" like the one he wears here and in Vermeer's Solider and Laughing Girl (JV10). Willem's presence as model is appropriate beside his mother, whom he resembles, and his role is in keeping with what we know of his "roguish" character. Documents discovered by Montias record that Willem verbally and physically abused his sister, repeating the behaviour of his estranged father who insulted and beat his wife and daughter. Neither Vermeer nor his mother-inlaw protected Catharina or impeded Willem's behaviour,

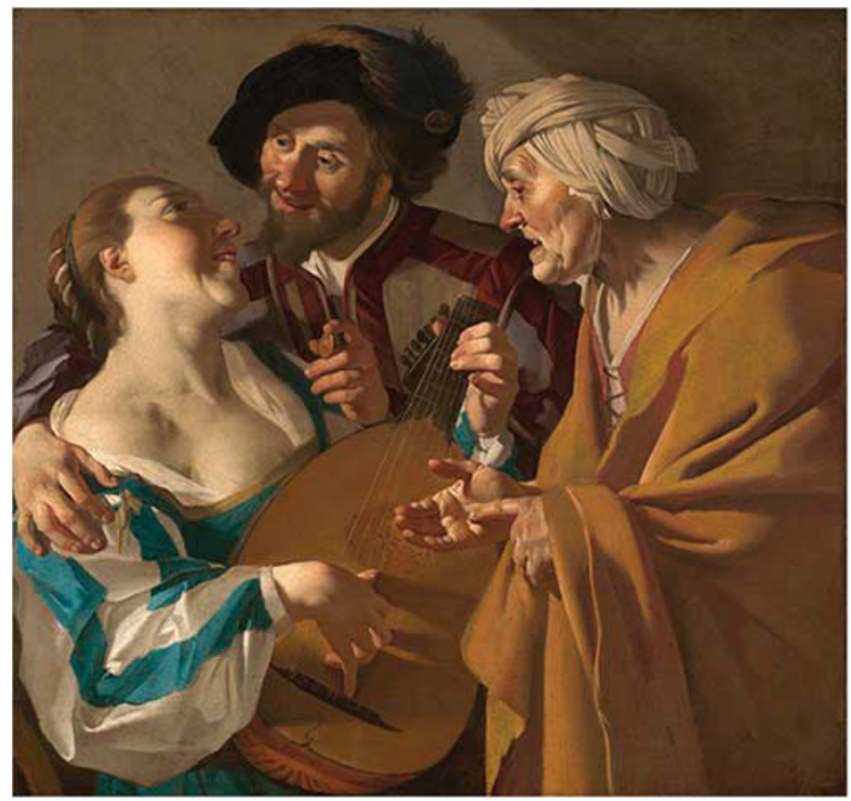

Figure 9 | Dirk van Baburen, Procuress, ca. 1632, Boston, Museum of Fine Arts. Copyright: Boston Museum of Fine Arts. This image is reproduced for the purposes of academic review (fair use). It is not covered by a CCBY 4.0 license.

presumably because they were unable or unwilling to overcome the entrenched family dynamic. Willem was eventually placed in a house of correction (Montias, 1989: 154-70, 320).

In contrast to Rembrandt's aggressive challenge to his in-laws and to us, Vermeer's passive and submissive toast reflects his different circumstances and artistic sensibility. Vermeer moved into his in-laws' house, was financially dependent on them, and had to assimilate to their Catholic religion and peculiar household. His role as musician assistant to his mother-in-law as procuress prefigured his real-life function as her legal and financial assistant late in his life (Montias, 1989). The incestuous relation of Willem as model for the client fondling his sister as whore presumably reflected something of their peculiar intimacy. Vermeer's provocative gesture indicates that he takes auto-erotic (masochistic) pleasure at this spectacle, perhaps reflecting his personal perversities or practical acceptance of the family dysfunction. ${ }^{10}$

Although he appears to cower across from what looks like a three-headed hydra of his in-laws, Vermeer can also be understood as a painter seated before his easel, his phallic instrument a substitute for his brush, toasting his own work, which effectively reduces the others to his creations, or products of his (naughty) imagination. All the world is a studio, just as all the world was a stage for Shakespeare, or life was a cabaret for Christopher Isherwood, varieties of mise en abyme in which the modernist artist through his particular medium represents the world. Vermeer serves as mediator for the viewer, who is likewise meant to take voyeuristic pleasure in the "dirty laundry" or family secrets that he airs, following Rembrandt's precedent. On a more profound level, the distinction between Willem's active physical touch and Vermeer's passive psychological observation indicates his greater self-consciousness and interiority as a painter, also in relation to Rembrandt as his aggressive predecessor within their evolving tradition (Riegl, 1998 [1899]: 169-72). Vermeer is more self-conscious both in a negative sense (embarrassed) and a positive one (aware). His self-effacing role seems humiliating, yet allows him to produce a scene of more compelling physical and psychological or emotional realism. 
The relations between Vermeer's family models to one another and to the roles they represent potentially go deep, yet he does not depict a scene from his life (in a Romantic mode) or a family allegory. Nor does he depict a traditional genre scheme like Baburen, or family members in the guise of a biblical story like Rembrandt, or anonymous models (in some cases family members) in anecdotal genre scenes such as those by Vermeer's friend Gerard Terborch and his contemporary in Delft Pieter de Hooch. Vermeer makes up or pretends nothing: he simply portrays his family members as models in costume, posed in the guise of a conventional subject, which produces relevant associations. The carpet thrown across what looks like a bench obscuring the figure's lower bodies precludes any narrative dimension. Vermeer depicts a studio situation, an account of his concrete circumstances as the foundational conditions of his art, and a painting about painting. His predecessors and peers also created paintings as paintings, yet he distilled his tradition through his concentration on rigorous observation and naturalism and his self-conscious candor about his own process.

\section{Vermeer's Letter Reader and the birth of the "Delft Interior" and "Delft Interiority"}

Vermeer's following Drunken Girl Asleep (Fig. 10) portrays Catharina as model asleep at a table with remnants of a meal in a dark room. The carpet-tablecloth is thrust up at one corner as if part of a process of clearing and cleaning, or perhaps an altercation of some kind, with an out-turned chair to the right, and a view through the open door of a more brightly lit empty room beyond. The composition echoes earlier scenes by Rembrandt's student Nicolaes Maes (Hollander, 2002). The fragment of a painting with cupid's foot beside a mask is usually interpreted as a reference to the drunken, sleeping girl's dreams or nightmares of love (Gowing, 1952: 51). X-rays and autoradiography further reveal that Vermeer removed a man in a red jacket standing before the mirror in the next room, in two different hats, as well as a dog in the threshold facing him (Ainsworth et al., 1982: 26, 97 n. 21).

In Vermeer's earlier conception, the man could have been seated at our side of the table and finished the beer in the overturned glass and pitcher, got up and pushed the out-turned chair away to the right, and checked his appearance in the mirror, before leaving, watched by the dog guarding his vulnerable mistress. Both the earlier and later conceptions make sense as different stages in the aftermath of a meal, whereas Vermeer's changes and omissions simplified and clarified his composition, yet also left traces of unknown mysteries. Vermeer apparently based the setting on his empirical observation of the "interior kitchen" in his house with a view of the front hall beyond with its shuttered windows and mirror in an ebony frame seen in his other paintings (Figs. 5 and 11) (Binstock, 2009: 117-123). The man in the red jacket before the mirror who was made to disappear was presumably based on Willem as model.

One can distinguish between what is now visible in Vermeer's painting or would have been to a viewer in his time, such as his patron Van Ruijven who bought this work, and the deeper understanding that is potentially accessible to us, through invisible earlier layers of the composition revealed through technical analysis, and their elucidation in relation to connections with his other paintings and what we know of his house and household. At stake are two different views of art. Instead of a message for his contemporaries. Vermeer's process of composition in his Drunken Girl Asleep reveals his conflicting artistic impulses. On the one hand, he emulated a straightforward narrative of the type depicted by Maes, although made more naturalistic and convincing through Vermeer's careful

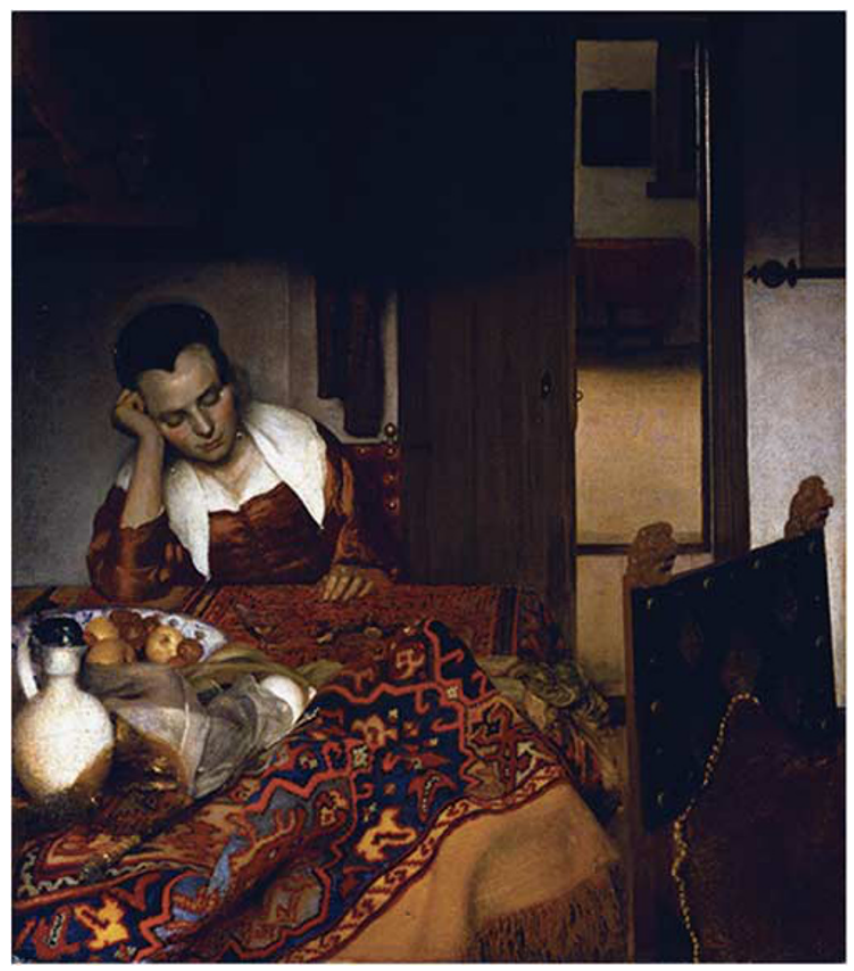

Figure 10 | Vermeer, Drunken Girl Asleep, ca. 1656, New York, Metropolitan Museum (JV6). Copyright: Metropolitan Museum New York. This image is reproduced for the purposes of academic review (fair use). It is not covered by a CC-BY 4.0 license.

observation of his surroundings. On the other, he aspires to a contrary modernist conception of the model and setting as a studio situation. More specifically, his scene betrays a disparity between the dark, chaotic subjective experience of the figure in the foreground, and the brighter, clearly ordered, empirically observed empty room in the background, or between interiority and interior.

Vermeer reconciled these conflicting dimensions in his following Letter Reader (Fig. 2), which is widely recognized as his first true interior and the prototype of his mature paintings. The geometric space of the room is clearly defined and enclosed by the carpet-covered table in front and a trompe l'oeil curtain at the right on the rod above, meant to "fool the eye" as if to be drawn across the painting, or the room itself. Scholars have cited precedents in paintings of figures in a corner of a room by Terborch and De Hooch, and Carel Fabritius' scenes with plain walls struck by bright light. Delft Church interiors from around 1650 employed similar distant-point perspectives, organized the picture space around a central pillar much as Vermeer does around his figure, and even included the same type and colour of trompe l'oeil curtains. A camera obscura, already used by Fabritius and detected in elements of Vermeer's prior compositions, has often been invoked as a likely aid in his observation of the play of light on the walls and window panes, the carpet, and particularly the tiny granule-like dots on his model's costume (Gowing, 1952: 98-102).

Scholars have not explained how Vermeer synthesized such diverse strategies to make this remarkable leap into his artistic maturity. Conversely, the strict empiricists simply assumed that Vermeer depicted rooms in his house, but did not address his pictorial sources or strategies. Vermeer was only able to combine the compositions and techniques of diverse artists by grounding himself in empirical observation of an actual room, specifically 


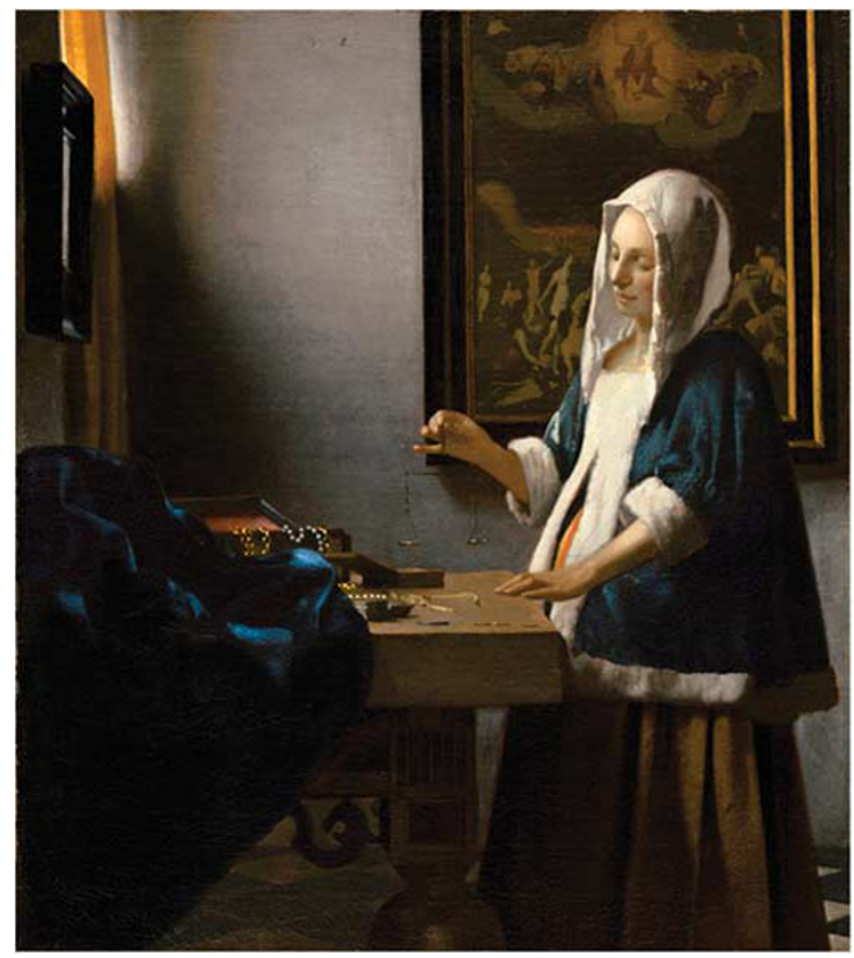

Figure 11 | Vermeer, Woman with a Balance, ca. 1662, Washington D. C., National Gallery (JV15). Copyright: National Gallery Washington D. C. This image is reproduced for the purposes of academic review (fair use). It is not covered by a CC-BY 4.0 license.

the western (right) upstairs "front room" of his house that came to serve as his studio (Figs. 2, 4 and 5). His achievement could be characterized as the invention of "the Delft interior," anticipated by earlier artists and imitated by later artists, yet never executed with this level of specificity.

The closest comparison to this new paradigm is Jan van Eyck's invention of "the Bruges Interior" over two centuries earlier in his Arnolfini Portrait from 1434 (Fig. 12). The scene shows a "doll house" type with a missing "fourth wall" coinciding with the picture plane, which he had explored in earlier paintings and illuminated manuscripts. The spherical mirror on the back wall reflects the artist in his red turban standing in the threshold of the fourth wall, a mise en abyme related to examples cited by Gide. Van Eyck likely used such a mirror as an optical aid in his empirical observation of particular persons, costumes, objects and presumably an actual room, a forerunner of the camera obscura, if he did not employ an actual camera as David Hockney has claimed (Hockney, 2006). The notarial inscription on the wall above the mirror-"Johannes de Eyck fuit hic [Jan van Eyck was here] 1434 "- -specifically testifies to his presence as legal witness for the morganatic marriage contracted by his sitters (Schabaker, 1972 and Dhanens, 1980: 195-9). Van Eyck also marks his presence as observing artist, inaugurating genre painting.

In place of the fourth wall, Vermeer introduced a trompe l'oeil curtain, echoing the one draped over the room's window, to suggest the picture plane itself as an Albertian "picture window". ${ }^{11}$ Women reading letters were a common subject in paintings by Terborch and others. Yet Vermeer's scene is difficult to read as an anecdotal narrative because he self-consciously barricaded his figure behind the carpet-covered table, and the trompe l'oeil curtain calls attention to his painting as an artificial construct. Vermeer underscores his idea through his model's face reflected in the window panes, which shows her from a different angle, with her eyes cast down, her lower collar exposing more

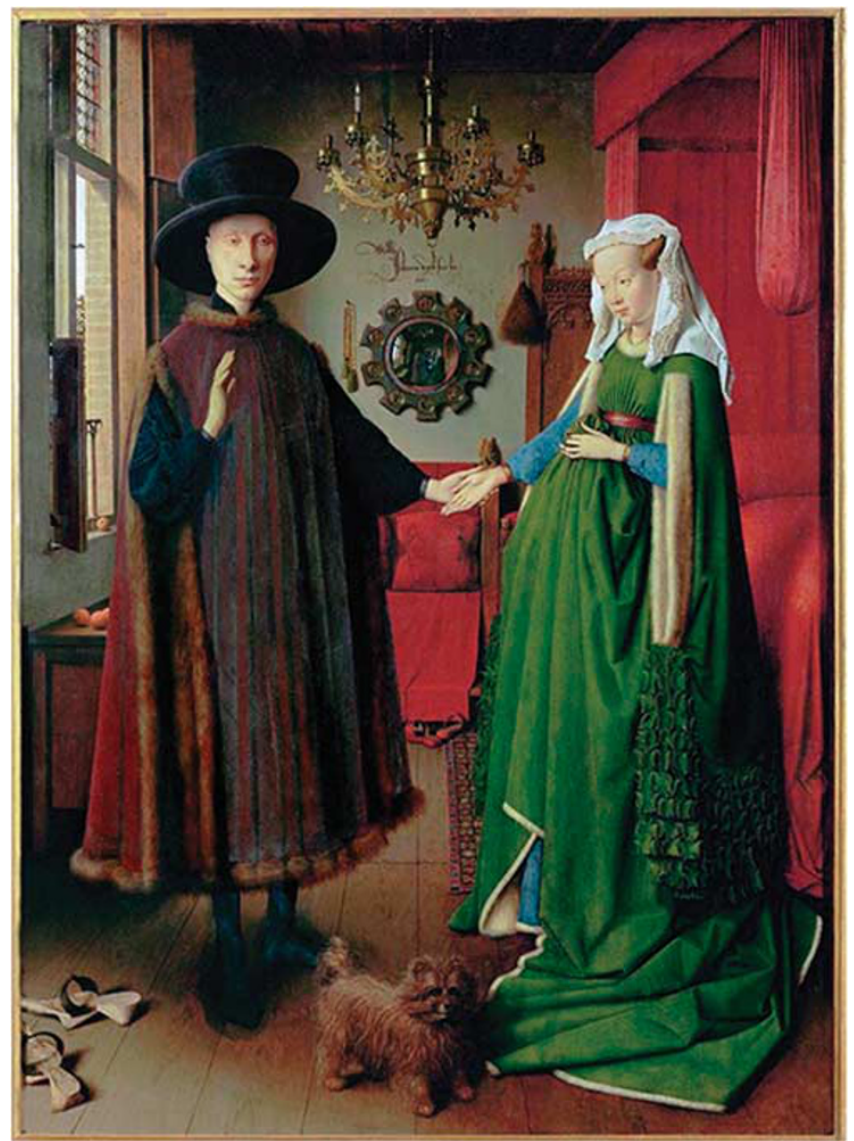

Figure 12 | Jan van Eyck, Arnolfini Portrait, 1434, London, National Gallery. Copyright: National Gallery London. This image is reproduced for the purposes of academic review (fair use). It is not covered by a CCBY 4.0 license.

skin, closer to his approach in his prior Drunken Girl Asleep (Fig. 10). The reflection appears to preserve an earlier moment in Vermeer's process of composition. He thereby emphasized his wife as a particular model in the concrete environment of the right upstairs room as studio, which might also be described as the invention of "Delft interiority". 12

Vermeer's Letter Reader is usually dated 1657, the year in which Catharina gave birth to the couple's second child Lijsbeth. Her letter thus calls to mind both love and its result, pregnancy and a child, further evoked by the light striking her, and the bulging carpet on the table that overturns the bowl with its fruit, including some with exposed pits, potential seeds of new life. The rumpled carpet is the last echo of the carpet-curtain that precludes narrative in Vermeer's Procuress and the carpettablecloth that suggests cleaning or a disturbance in his Drunken Girl Asleep. X-rays reveal that Vermeer underscored his idea through a large painting of cupid on the back wall that he then painted over as perhaps too obvious a reference, or because he preferred the impact of the plain wall. Scholars have often compared Vermeer's scene to an annunciation, in which Mary reads the bible, the word made flesh, impregnating divine light streams through windows, fruits of paradise rest on ledges, and curtains or barricades preserve the virgin's inviolate state, as a vessel of life contained by her setting in turn, in a play of interior and interiority. Vermeer was self-conscious about his tradition, extending back to the earliest Netherlandish genre paintings (Fig. 12) and religious images that were also striking works of art, which he assimilated to his own domestic idiom. 
Scholars frequently remark-it has become something of a cliché-that Vermeer's pristine interiors did not reflect his tumultuous family life, eventually including eleven children. Yet his early Procuress and Drunken Girl Asleep draw on the raucous family environment downstairs, he alluded to his children in depictions of his pregnant wife such as his Letter Reader, Woman with a Balance, and Woman in Blue (Figs. 2, 3 and 11), included one of his young children among the figures in his Little Street (Fig. 4) and View of Delft (JV18), and as they matured employed his eldest daughters as models for his later paintings (JV19-20, 23-24, 30-31). The cliché is nevertheless correct insofar as Vermeer did not portray anecdotal narratives based on his family life, but rather the modernist circumstances of his studio with family members as models, eventually extended throughout his house. Vermeer needed empirical grounding as well as a refuge from his milieu, which he found in the upstairs front room, in an atmosphere of peace, calm, stillness, and order. This was a de facto studio even if his mother-in-law had not yet made the room permanently available to him at that time.

In a characteristic mix of insight and opacity, Lawrence Gowing declared that "a whole generation of artists, imitating in one form or another Rembrandt's humane understanding, was grappling with a knot which Vermeer's temperament alone led him to cut" in his Letter Reader insofar as he depicts "the simple, timeless life of a painter's model" (Gowing, 1952: 34-5, 101). Gowing put his finger on a central nerve of Vermeer's art in emphasizing the life of the painter's model, yet his qualifiers "simple, timeless" betray his disinclination to discuss Vermeer's family members as models, whose lives were complex and dynamic. Gowing also repeatedly returned to the idea that "Vermeer's handling of the genre problem, the description of current life, is an evasion of it," and his characterization of the painter as emotionally handicapped. He thereby reduced Vermeer's art to a personal pathology. An alternative solution is provided by Gowing's own insight that Vermeer portrayed his models as models, that is, particular persons in the studio. He did not avoid life; rather, he avoided anecdotal narratives as in his peers' scenes, which make their models appear false, like actors. Vermeer presented his family members more honestly as models in his studio, in modernist paintings about painting.

Gowing significantly recognized Rembrandt's Bathsheba of 1654 (Fig. 7) as a direct source for the kneeling woman in Vermeer's early Diana and her Companions of ca. 1655 (JV4). Most Rembrandt scholars identified Rembrandt's common-law wife Hendrickje Stoffels as his naked model for Bathsheba; compositions by Rembrandt's students depict him painting her nude in the studio, so the idea was broadly recognized (Bredius, 1969, Alpers 1998: 147-158). Because he squandered Saskia's inheritance (Fig. 6), which she left with specific conditions to their son Titus born shortly before her own death, Rembrandt was later unable to marry his former maid Hendrickje. She nevertheless gave birth out of wedlock to their daughter Cornelia in October of 1654. Presumably in response to her pregnancy, or possibly Rembrandt's painting, the Calvinist elders of Amsterdam sent Hendrickje a summons to answer the charge of adultery ("whoring") in June of that year and eventually barred her from Church, which Rembrandt did not attend (Strauss and van der Meulen, 1979: 318, 320). Bathsheba had committed adultery with king David and later gave birth to their son Solomon. As with his earlier Prodigal Son in the Tavern (Fig. 6), Rembrandt drew on his own circumstances, showing Hendrickje as Bathsheba sadly holding David's letter, facing a conflict between love and (public) morality (Binstock, 2009: 66-9, 126, 156-9). Through his emphasis on his model and her particular circumstances, already a form of modernism, Rembrandt established an extraordinary depth of interiority to match her sensual exterior, arguably the first thinking nude in the history of art. Yet there is no interior to speak of: Bathsheba's golden robe glows in the darkness, presumably meant to evoke ancient Israel.

Vermeer first responded to Rembrandt's painting in his Diana the following year, which includes apparent likenesses of Catharina, in one case wearing the same dress as in his Drunken Girl Asleep. He then returned to Rembrandt's Bathsheba two years later in his Letter Reader (Fig. 2), likewise depicting his (pregnant) wife as model reading a letter, yet dropped the historical frame, providing her with her own contemporary physical and psychological space, reconciling interior and interiority. To adapt Gowing's formula, Vermeer "cut the knot" of life and art in Rembrandt by collapsing them: not the artist's outside life introduced by way of his model into his painting's fictional narrative but rather the modernist conditions of the painter's wife as model in the studio. Vermeer's Letter Reader thus celebrated not only the moment of love become new life, but also his studio as incubator of his own birth as a mature artist, the Delft interior, and Delft interiority.

\section{Vermeer's Music Lesson as non plus ultra}

Vermeer followed his Letter Reader with his Woman with a Pitcher and Milkmaid (JV8-9), dispensing with the barricade and the trompe l'oeil curtain, and including open space and then part of the floor. His three successive compositions present a consistent development in the arrangement of the figure, furniture and space of the rooms, and oscillate in emphasis from light, colour and surface detail to volumes integrated in space through muted tones, to a synthesis of these complimentary concerns. ${ }^{13}$ Vermeer also moved from Catharina as his model in the same yellow jacket with black stripes on the sleeves, with and without a head scarf, to the family maid Tanneken Everpoel as model for the milkmaid, as Montias proposed (Montias, 1989: 160). Vermeer specifically portrays her in the "little back kitchen" (Fig. 5), her rounder, bulkier, rougher body surrounded by similar kinds of objects. Here Vermeer assimilated his gradual formal development and a traditional subject from the pictorial tradition to his observation of a particular person, objects and room, distinctive in their lowly concreteness, achieving an early highpoint in naturalism of the interior and interiority.

Vermeer then turned to interiors with multiple figures. $\mathrm{He}$ started with half-lengths of Catharina and Willem as models in his upstairs studio for his Soldier and Laughing Girl (JV10). Fulllength figures in his Glass of Wine and Girl with a Wineglass (JV11-12) inhabit entire interiors based on the front hall, including its stain glass window and floor of checkerboard red and black ceramic tiles that match the stoop in his Little Street (Fig. 4). In his Glass of Wine he fudged a second pair of windows in the back corner, and in his Girl with a Wineglass he employed new models, most likely his sister Gertruyd and her husband doubling as enthusiastic and melancholic suitors. Vermeer's Concert (JV13) returned to his wife, brother-in-law, and motherin-law as models, a connection with his Procuress he underscored through (the original of) Baburen's Procuress on the back wall. $\mathrm{He}$ also introduced a new floor of costly black and white marble squares, likely elaborated from the earlier simpler one (Fock, 2001). These scenes of (low) flirting, wine drinking and music playing in elegant (high) settings borrow from and come close to the anecdotal narratives of his peers. Yet nothing in Vermeer's compositions contradicts his modernist paradigm of empirical observation of family models in the rooms of his house along with its furniture, paintings and objects.

Vermeer's Music Lesson (Fig. 1) embodies the culmination of his multi-figure interiors. The virginal player was based on Catharina as model, in the same yellow jacket with black stripes 
on the sleeves that she wears as his model for his Letter Reader (Fig. 2), Woman with a Pitcher, Concert and Little Street. The gentleman with shoulder-length locks was likely loosely based on the ageing Willem as model, whom we see in Vermeer's Procuress (Fig. 6), Soldier and Laughing Girl, and Concert. The traditional title implies that the gentleman, who presumably put down the viola da gamba to listen to the virginal player, is her "teacher" (or does she teach him?). The inscription on the virginal MUSICA LETITIAE CO[ME]S MEDICINA DOLUR[UM] ["Music is the companion of joy, the balm of sorrow"] calls to mind the traditional association of music with love as pleasure and pain. Gowing identified the painting behind the gentleman cut off at the right edge of the picture as one by or after Baburen of the story of Roman Charity, about the starving prisoner Cimon saved by drinking his daughter Pero's breastmilk. The scene represents in Gowing's phrase "man's abject dependence on woman," and an implicitly erotic relation between father and daughter (Gowing, 1952: 52, 126-7). As in Vermeer's prior Concert, the painting on the wall parallels his figures' relations and illustrates Vermeer's evolving tradition of genre painting. The older gentleman presumably imagines himself in a similar relation to the virginal player as Cimon to Pero (sucking her breasts), so that Baburen's low physical, tactile, sensual relation is transformed into Vermeer's high psychological, visual, conceptual one, a more refined version of the juxtaposition of Baburen's Procuress with the more restrained figures in Vermeer's Concert, or the dichotomy of Willem as groping client and Vermeer as thinking painter in his Procuress (Fig. 8).

Vermeer based his interior on the front hall, yet doubled the windows and the length of the room through his perspective scheme, anchored in the patterned floor that rises up at an unusually high angle. The room's extended depth makes the figures appear too small, as in a doll-house. Vermeer also shows disparities in the reflection in the mirror above the virginal (Fig. 1a), elaborating on the disparities of his model's face reflected in the window panes in his Letter Reader (Fig. 2). The reflection, showing the model's head from above, is at odds with the mirror's higher angle in the painting, and her head is turned further towards the gentleman. The table is also located directly behind her, and behind that we see the feet of Vermeer's easel and a box-like object that Gowing identified as a portable camera obscura (Gowing, 1952: 121, 125-6). These circumstances leave no room for the chair and viola da gamba on the floor between the model and the table, and would place Vermeer's easel at the center of the room, behind the first pair of windows, that is, at the back of the normal-sized front hall, the floor board of which is reflected in the mirror behind the feet of Vermeer's easel. All these circumstances can be explained insofar as Vermeer doubled the windows and size of the room, depicted the table further back, introduced the chair and gamba in between, and halved the mirror's angle from the wall, thereby placing himself at his easel twice as far back, in the viewer's position. He also combined volume and surface texture, colour and light in continuous space with a complexity and delicacy of detail surpassing all his previous compositions. The result is an extraordinarily spacious and luxuriously appointed interior, unimaginably large for a Golden Age room let alone one in Vermeer's modest house. His "Delft real estate porn" surpasses in elegance Dutch palaces in his time, Buckingham palace where the painting now hangs, and even the imaginary Manhattan apartments in Woody Allen's films.

Gowing identified the flattened optical forms in the mirror as characteristic of a camera obscura image as well as Vermeer's more optical approach in the second half of his career (Gowing, 1952: 121). The mirror hung at an angle within the rectangular room further approximates the small mirrors placed at an angle in a portable camera that served to reinvert the image inverted through the front lens. Vermeer's dark room [camera obscura] thus stands-in for a camera, and the mirror within it serves as mise en abyme. As in his earlier Letter Reader, the disparity in the reflection contrasts his empirical observation of a particular model and room-"Johannes Vermeer was here"-with his composition as autonomous imaginary construct, an ambiguity that also applies to his figures' interiority. Vermeer reflected at his easel approximates a voyeur within his scene, the virginal player's turn manifests her hidden reciprocated desire for the gentleman, and their juxtaposition with the Roman Charity evokes Catharina's fraught relation to her own estranged father, extended to her sadistic brother and (masochistic) husband. ${ }^{14}$ He thereby created a more psychological, interiorized version of the "love triangle" in his early Procuress of himself as masturbatory observing musician-painter, Catharina as whore, and Willem as groping soldier-client. Vermeer's Music Lesson achieved a non plus ultra or point beyond which he could not go in interiors and interiority, in extended space, luxurious elegance, psychological complexity and self-conscious reflection.

\section{The depths of interiority in Vermeer's Woman with a Balance and Woman in Blue}

Vermeer had to move once more in a new direction, and in his following Woman with a Balance and Woman in Blue (Figs. 3 and 11) he returned to his inaugural scheme in his Letter Reader (Fig. 2) of his wife as model in the corner of a room. Vermeer's patron did not buy his Letter Reader, or Vermeer refused to relinquish what constituted the moment of his own birth as a mature artist, so the work remained in his house as a pictorial model (see Supplementary Appendix B). Both the later paintings show Catharina visibly pregnant with a large spherical bulge in her mid-section covered by loosely fitting (maternity) jackets. She also wears a beige-brown maternity skirt, underscored in Vermeer's Woman with a Balance by a scarlet drawstring tracing the curve of her distended stomach, glimpsed between the suggestively slit-like opening of her fur-trimmed jacket. His Letter Reader already made allusion to Catharina's pregnancy in a number of ways, but it did not yet occur to him to depict her as obviously pregnant, or she was not that far along, or had she been, he would not have used her as his model, which was possibly one reason he turned to Tanneken as alternative model for his Milkmaid. Showing a pregnant model was after all unprecedented, which is why some scholars deny the idea, although they thereby deny Vermeer's originality.

Vermeer now de-emphasized the interior he had gradually mastered in favour of greater interiority. Little of the room is visible in either scene, and he reduced linear perspective and foreshortening to a minimum. In both cases Catharina stands in the foreground as a swollen pillar of space, more accurately compared with a bell or upside-down flower bud. Vermeer's Woman with a Balance is enveloped in a Rembrandt-like darkness with light peeking through the curtained-covered window above, highlighting the bulge of Catharina's stomach, recalling the annunciation metaphors of impregnating divine light and the vessel within a vessel. As in his prior Concert and Music Lesson, the painting on the wall a form of mise en abyme, relates both to his figure and his pictorial tradition. He thereby transformed the conventional moralizing motif of a figure weighing gold related to the necklaces draped over jewel boxes and the coins on the table. Catharina holding a balance naturally recalls St. Michael weighing souls hidden directly behind her in the Last Judgment, evoking a parallel between an earthly "first" birth in Vermeer's home and the heavenly "second birth" of the resurrection. Catharina's pregnancy was both a material fact (and 
good reason to need money as the wife of an impoverished painter) and something immaterial, a form of interiority, reflected in her mysterious, Mona Lisa-like smile.

Vermeer asserts both kinship and rivalry between his secular genre painting and the sacred image behind, which was displaced from the altar of a church, most likely as a result of iconoclasm and the Reformation, to the wall of Vermeer's bourgeois home as an object of aesthetic and financial value, as it had always been. The Last Judgment was specifically relevant to Vermeer's Catholic household insofar as unbaptized children were not allowed to enter heaven (the couple had lost several children by this point). The way Catharina holds an empty scale has also been identified as a folk practice for determining the sex of an unborn child (the couple's surviving children at this point were all girls) (Carstensen and Putscher, 1971). Catharina with her scale further approximates the zodiac sign Libra, related to the heavens, and possibly, in keeping with her heavier clothing, alludes to the child's expected birth date in October. ${ }^{15}$ For Vermeer, genre painting does not involve a picturesque story or a symbolic or allegorical moralizing message of an isolated work. Rather, his painting engages his self-conscious modernist reflection on the everyday circumstances of his process of creation as part of his broader development. His subject is explicitly creation, transferred from a cosmic religious context to that of his home, the creation of new life in his wife, and his creation of a new painting based on her as model, elaborating on his earlier paintings. ${ }^{16}$

Vermeer's Woman in Blue is a much simpler composition, which omits the left sidewall and corner window that we can infer from the light that diminishes towards the right, creating a contrapuntal range of muted tones. The space is defined solely by the overlap of the table, chairs and Catharina's girth, more subtly defined by the folds of her thin, light-blue maternity jacket, appropriate for spring or summer. On the table lie a pearl necklace, partly covered by a piece of paper, next to a bunched-up cloth and open box hidden in shadows that presumably contained these items. Previous scholars have placed Vermeer's Woman in Blue chronologically before his Woman with a Balance on the assumption that the simpler composition preceded the more complex one, or simply echoing earlier scholars. Yet Vermeer's development manifests consistent oscillation between complexity and simplicity. His Woman with a Balance is related to his prior Music Lesson in its use of a painting within the painting and glowing colours and shadows (Figs. 1 and 11), whereas the brighter lighting and pastel palette and straightforward conception of Woman in Blue are closest to his following Little Street (Figs. 3 and 4).

Although simpler as a composition, Woman in Blue also reveals a greater depth of self-consciousness and interiority in its conception. Vermeer's repetition of Catharina as pregnant model in two consecutive paintings underscores her nearly yearly pregnancies, reflecting the actual circumstances of their home, as a rhythm of life. He further made his return to the precedent of his Letter Reader explicit as a repetition by depicting Catharina in the same activity, pose and profile (Figs. 2, 2a, 3 and $3 \mathrm{a}$ ), yet underscored subtle differences in his model, a veteran of marriage at thirty-two, pregnant with a fifth surviving child, yet another girl as it turned out. She holds the letter, presumably the same letter, a metaphor-or more than that-for her recurring condition, closer to her face, because her eyesight had worsened or Vermeer had learned to observe his model more carefully.

Mariët Westermann compared Vermeer's compellingly vivid scenes to a "proto cinematic suspense, in that we have no idea what the next frame will be" (Westermann, 2003: 229). Yet the "next frame" implies an anecdotal narrative mode characteristic of Vermeer's peers that he moved beyond. The "cinematic" quality of his scenes more accurately involves his acute empirical observation of his models and their surroundings, closer to a movie (or camera) "still." Conversely, Vermeer's scenes have lent themselves to cinematic treatment, as with Peter Weber's film Girl with a Pearl Earring based on Tracy Chevalier's historical novel, which imagines Vermeer's eponymous painting as based on-in place of his eldest daughter Maria as model-an unknown maid's assistant (played by Scarlet Johannsen, who would go on to work with Woody Allen), provoking his wife's jealous lament: "Jan, why don't you paint me?" Weber significantly hedged his bets, presenting the pregnant Catharina dressed in a light-blue housecoat as in Vermeer's Woman in Blue (Fig. 3), corresponding not to the neglected and lamenting wife of Chevalier's fiction, but rather to Vermeer's wife as over-worked model within his modernist paradigm.

André Malraux, who coined the phrase musée imaginaire [museum without walls], observed that reproductions allow us to recognize Vermeer's family members as his models, and thereby provide a new chronology for and a new perspective on his oeuvre. Malraux cited Vermeer's repetition of an earlier format in his Woman with a Balance and Woman in Blue as a development that is not linear, so much as a helix, returning to the same place from a higher (or deeper) position (Malraux, 1951: 196). In his Woman in Blue Vermeer looked back to his young bride and his own youthful artistic promise in his Letter Reader-another facet of modernism and mise en abyme as a painting about a painting. He appears to show her looking back as well. She seems melancholy, in contrast to the mysteriously smiling Catharina in his Woman with a Balance, perhaps wondering where the beautiful moments had gone. Vermeer also implicitly returned to the precedent of Rembrandt's tragic Bathsheba (Fig. 7), measuring himself in his maturity against his great predecessor and the respective ambivalence of their wives as models. Without any interior barricades to protect her, Catharina's interiority is now more properly her own.

The life of the studio possessed its own dynamic history, for both models and objects (letters, paintings, maps), with layers of depth, reaching outside the picture to the artist's life, yet contained within his "still." The same map of Holland as in Vermeer's Soldier and Laughing Girl, rendered in monochrome brown, on a larger scale, and as a fragment in his Woman in Blue (Fig. 3), is more convincing in terms of our optical experience, like the interior and the model herself. Catharina's head and hair are delicately inter-mingled with the map, which suggests a parallel for her body as fertile Dutch earth, complementing the painting of heaven behind in Vermeer's Woman with a Balance. He later created literal companions for these paintings in his Astronomer of 1668 and Geographer of 1669 (JV22-23), in which he portrayed himself in his upstairs studio, dressed in Japanese kimonos, in metaphorical guise as observing scientist, measuring heaven and earth, paralleling Catharina as implicit embodiment of heaven and earth in the front hall below. Husband and wife, who carries her own "globe" inside her, are placed in implicit competition as creators of paintings and children, worlds within themselves, and forms of mise en abyme, within a self-conscious oeuvre that contains itself and its development en abyme. ${ }^{17}$

\section{Vermeer's Art of Painting as the apotheosis of genre painting} After exhausting seemingly every possible variation on a woman in a corner of a room, perhaps tiring of his wife as model or she of him, Vermeer turned his attention outside. His surviving urban landscapes The Little Street and The View of Delft, which portray his house and his town, offered an opportunity to master a different subject and to take objective distance on his art and life. 
When he returned home, he found his eldest daughter Maria was old enough to serve as his model, circumstances he celebrated in his Girl with a Pearl Necklace (JV19), which portrays her dressing up as an adult, taking her mother's place as his model and, to adapt Malraux's metaphor, turning Vermeer's oeuvre into a double helix.

Vermeer celebrated Maria as his model even more selfconsciously in his following Art of Painting (Fig. 13), as an explicit statement about the meaning of his art. He shows himself from behind, seated at his easel, dressed in the traditional Netherlandish slashed doublet and beret that he wears in his Procuress (Fig. 8). He used two mirrors to project himself into the scene, so that he is roughly twice the size he should be and would hit the chandelier if he stood, the inverse of his strategy in his Music Lesson (Hultén, 1949: 96-98). Vermeer's turned back draws us into his scene, underscored by the seductively twisting tapestry, the inviting floor pattern and his model's disarmingly modest lowered gaze, revealing the most perfect interior and interiority in the history of art, surpassing even his Music Lesson. The painter concentrates at this moment on observing and painting his model's laurel crown on his canvas, which is usually interpreted as a symbol of (historical) triumph. Alternatively, the laurel can represent poetry and a piece of nature, and as mise en abyme stands for the poetic naturalism of his composition as a whole, just as Vermeer's painting stands in for his vision and oeuvre as a whole.

Such interpretations depend on the identification of the girl in relation to her attributes, which scholars have misunderstood in a way that echoes their misunderstanding of the meaning of Vermeer's art. Since 1967, she has always been identified as a personification of Clio, the muse of history writing (Hultén, 1949: 90-92). This identification is at odds with some of her and some of Clio's attributes, with Vermeer's practice as a genre painter, and with the testimony of his own widow and mother-in-law, who both described his "painting... in which 'Painting' [de schilderkonst] is being depicted (or) rendered as a role (or) personified as a character on a stage [wert uytgebeelt]" (Binstock, 2009: 171-83). ${ }^{18}$ The girl serves as a model for "Painting" [Pictura]. Her attributes include her laurel crown that indicates poetic achievement rather than historical triumph, her curls and raised eyebrows that symbolize passion and thought, her light-blue drapery that changes colour in the light as a naturalistic version of her "garment of changing colours," and her chief attribute, the light rays bathing her from the unseen window.

Pictura's mask of imitation is visible on the table, beside a drawing as Painting's foundation, a blue and yellow fabric overhanging the table's edge as another garment of changing colours, and a large volume at the back representing history or poetry. Vermeer's model is echoed by female personifications of Painting in the tapestry, with a similar band at the bottom of her dress as garment of changing colours, and to the right of the cartouche on JC Visscher's map of the Netherlands, wearing laurel and holding palette, brushes and maulstick, opposite Geographia [geography] with a compass on the left. ${ }^{19}$ All three personifications illustrate Pictura [literally "picturing"] in different media, all local Netherlandish craft traditions, echoed by the chandelier with the Habsburg double-eagle above.

Vermeer's model takes up a trumpet (of fame) and a book (of history or poetry), presumably as external attributes associated with Painting. Yet these appear too heavy for her, the trumpet is upside down and the book closed, and they would not be included on the depicted painter's canvas. The attributes are clearly studio props, and the personification his young daughter serving as his model dressed up in costume. Vermeer playfully subverts the symbolic vocabulary of allegory to overturn the

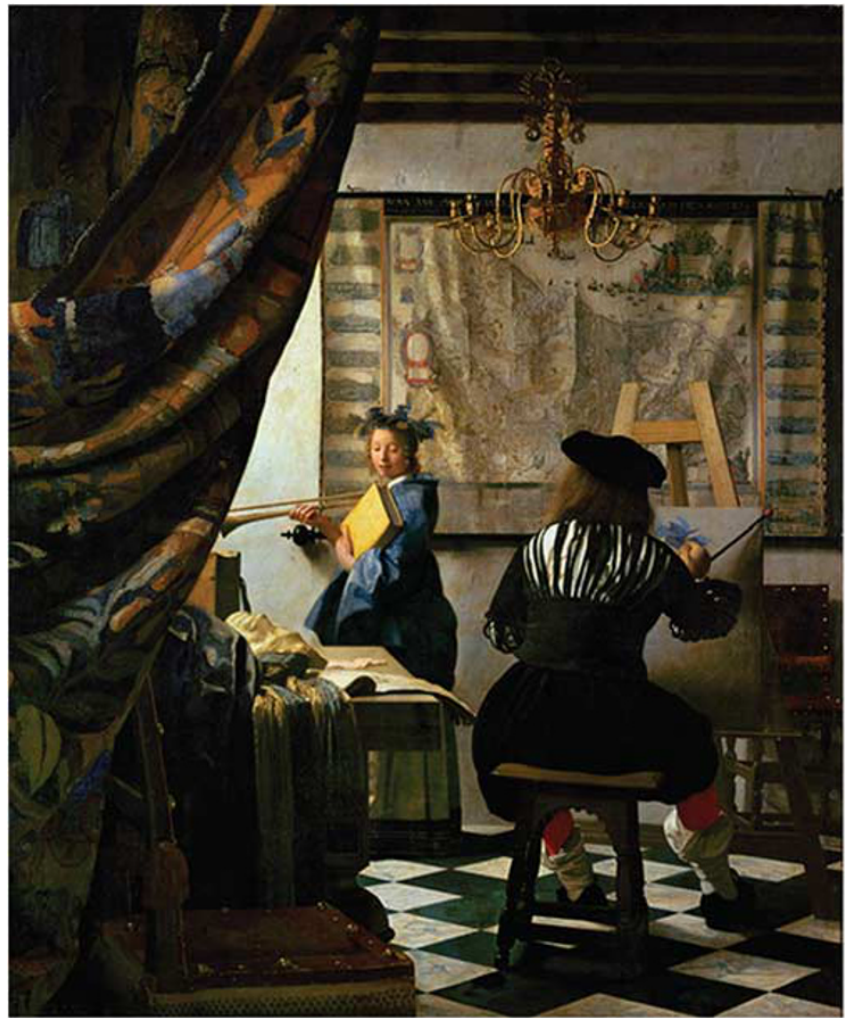

Figure 13 | Vermeer, Art of Painting, ca. 1667, Vienna, Kunsthistorisches Museum (JV20). Copyright: Kunsthistorisches Museum Vienna. This image is reproduced for the purposes of academic review (fair use). It is not covered by a CC-BY 4.0 license.

hierarchy espoused by writers on art praising allegory and history painting as the highest category over scenes of everyday life as the lowest. For Vermeer, painting, more specifically Netherlandish painting [de schilderkonst], is about the people and things he knows and loves.

Despite the low valuation of genre painting and his relative anonymity in his time reflected perhaps in his turned back (Vermeer was not mentioned by any writer outside his town), he understood the importance of his own art, and thereby anticipated his future recognition, an incomplete process in which we are still involved. The equivalent of the bust-length head study of his daughter as model that Vermeer begins to paint on his canvas in his Art of Painting, his Girl with a Pearl Earring (JV24) corresponded in his time to the lowest category within genre, yet is now world-historical because of its artistic qualities. This paradox is bound up with the belated definition and interpretation of genre painting. Since eighteenth-century French writers introduced the term and its theorization soon after by G. W. F. Hegel, commentators have emphasized how genre's "low" subject matter is made "high" through the painter's rendering, a dialectic of empiricism and subjectivity (Hegel, 1975: 168-9). Yet the pertinent issue is not genre's lowness, so much as the artist's familiarity with his subject, what he knows best, which transcends high and low; the principle also applies to Woody Allen's comic films. ${ }^{20}$

Like Allen and most other artists, Vermeer's development encompassed a decline in several of his later works. His "Love Letter," Allegory of Faith, Lady Standing at a Virginal, Lady Seated at a Virginal and Lady Writing with her Maid (JV25-29) move progressively towards darkness, linearity and artificiality, with expensively decorated, gaudy settings: a radical exteriority of the interior, closer to the elegant sets of Allen's Interiors and some 
of his later films. These late paintings also show the same roundfaced, overweight model in overly elaborate dresses, in some cases arbitrarily varied like the settings themselves, with little sense of interiority, in keeping with Joey's dichotomy in Allen's Interiors. Presumably as a result of his financial dependence upon his mother-in-law Maria Thins near the end of his career, Vermeer apparently employed her (more loosely) as model, and deferred to her choices and taste.

Most unsettlingly, she appears to have asked him in his Allegory of Faith (Fig. 14) to adapt the composition of his Art of Painting (Fig. 13) to serve her own Catholic agenda through religious symbolism, using herself as ungainly model for "Faith." Yet the naturalistic studio props subvert their ostensible symbolic purpose in turn. The crushed snake of Satan or heresy looks incongruous in a domestic interior, the earth is farcically dominated beneath Faith's foot, and the sphere suspended above (Fig. 14a), symbol of God and the universe contained in the human mind, is rendered as the pure exteriority of empty reflecting glass. Here the narcissistic Maria Thins as Faith presumably sees a reflection of her own face, whereas we see through the window of the front hall to the Protestant New Church across the canal in the bright light of day outside.

Vermeer's last two paintings, Girl with a Guitar and Lacemaker (JV30, 31), present a homely, yet engagingly sympathetic model with eccentric features, also recognizable in his earlier Girl Writing (JV23). She can be identified as Vermeer's second child Lijsbeth, who was seventeen, the age Montias estimated for the model in the first two examples, in 1674, the year before Vermeer's death (Montias, 1989: 197). These paintings move in a new direction of increasing interiority, the greatest of all in Vermeer's final Lacemaker, which effectively crops the interior to focus on Lijsbeth's inward attention to her task, echoing the painter's.

\section{The misfit paintings of Vermeer's secret apprentice: an interiority of her own}

Gowing beautifully characterized Vermeer's oeuvre as “a slender and perfect plume thrown up by the wave of Dutch painting at its crest" (Gowing, 1952: 17). This crest could also be identified with optical naturalism in Western painting. Yet Gowing's phrase implies that Vermeer's oeuvre was a spontaneous production of Dutch painting, whereas he self-consciously synthesized his predecessors and peers' best ideas to achieve his unique vision, which needs to be explained in particulars. Gowing's formulation might also lead us to confuse the perfection of Vermeer's oeuvre with scholars' imperfect accounts of that oeuvre.

Writing under the pseudonym Wilhelm Bürger around 1860, Théophile Thoré discovered Vermeer as an unrecognized genius and gathered together his recognized paintings and re-assigned many more paintings to him. Only half of these are now recognized as by Vermeer, and these did not include several of Vermeer's works. Since that time a relative consensus has formed, yet scholars do not agree about the order of Vermeer's paintings and some dispute the attribution to Vermeer of several "misfit" paintings normally included in his oeuvre that do not correspond to his approach. Girl with a Flute, Girl with a Red Hat, Portrait of a Woman, Mistress and Maid, Girl Interrupted at her Music, Woman with a Lute and Young Woman at a Virginal (MV1-8) all display qualities unknown in Vermeer: imbalance and imperfections, technical difficulties and glaring mistakes, distortions, a lack of an interior, relative darkness or blurred definition. These works also manifest a more subjective, less idealized sensibility of spontaneity, expressiveness and experimentation, including original and fascinating pictorial qualities such as the deliberate exaggeration of camera effects, and a different kind of interiority.

Portrait of a Woman (Fig. 15), with its flattened head, mongoloid-looking features, indiscernible hair, meringue-like drapery lacking volume or texture and stump of a hand, offers
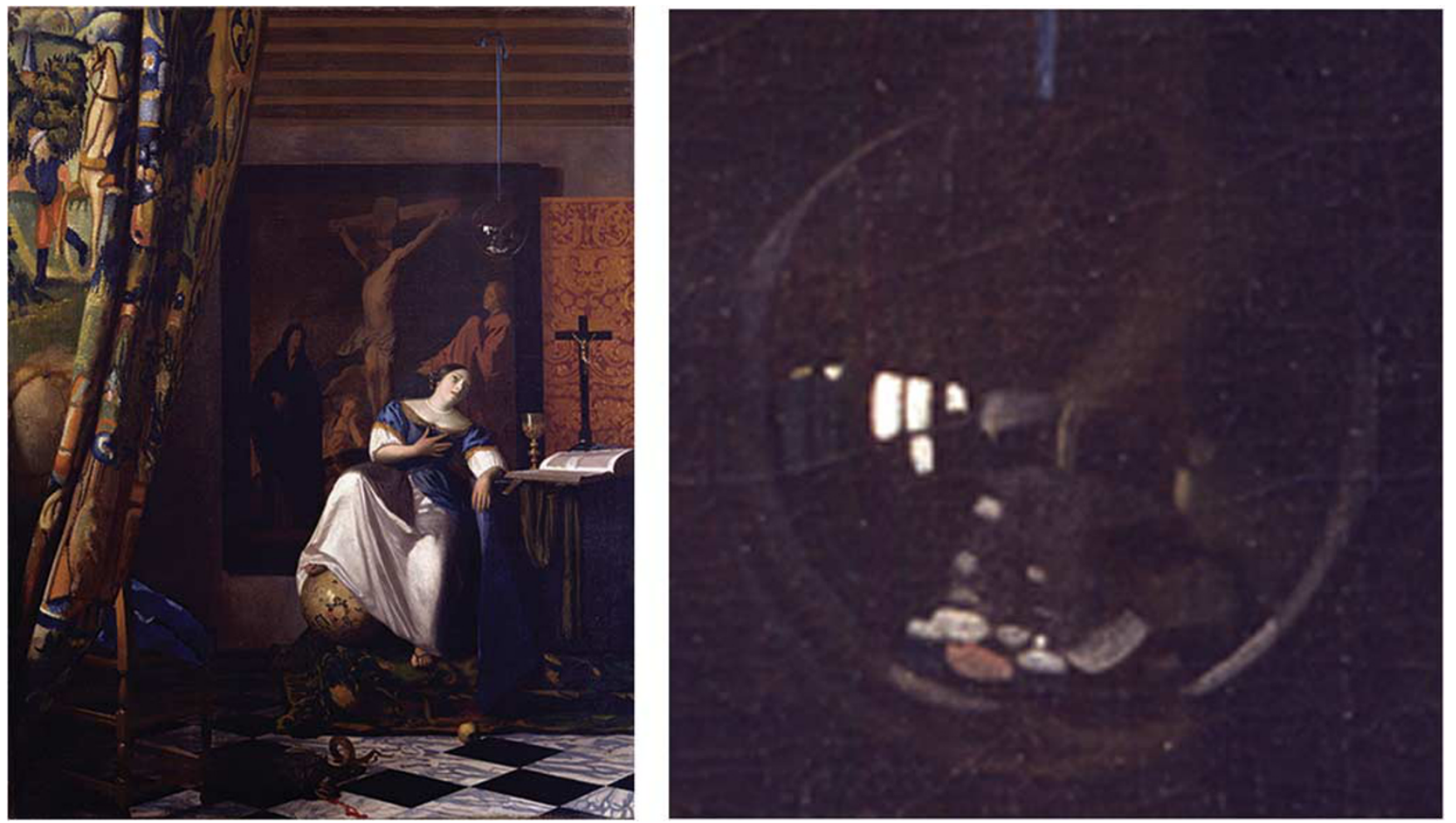

Figure 14 | Vermeer, Allegory of Faith, ca. 1671, New York, Metropolitan Museum. 14a. Detail: glass sphere. Copyright: Metropolitan Museum New York. This image is reproduced for the purposes of academic review (fair use). It is not covered by a CC-BY 4.0 license. 


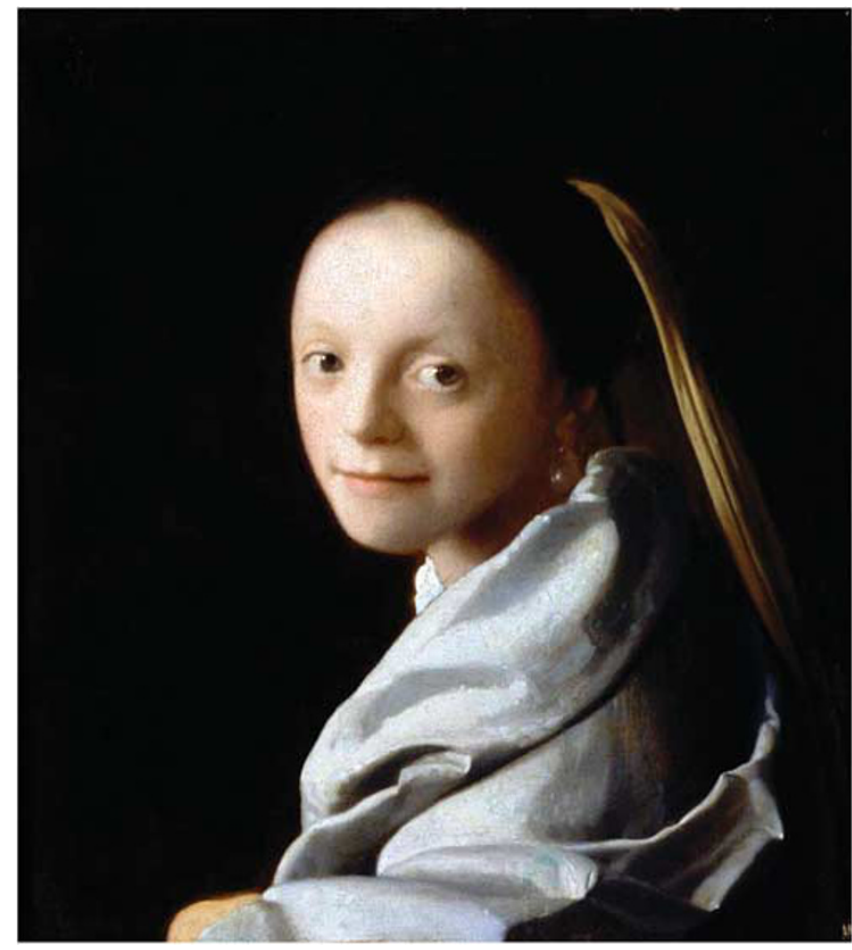

Figure 15 | Maria Vermeer?, Portrait of a Young Woman, ca. 1672, New York, Metropolitan Museum. Copyright: Metropolitan Museum New York. This image is reproduced for the purposes of academic review (fair use). It is not covered by a CC-BY 4.0 license.

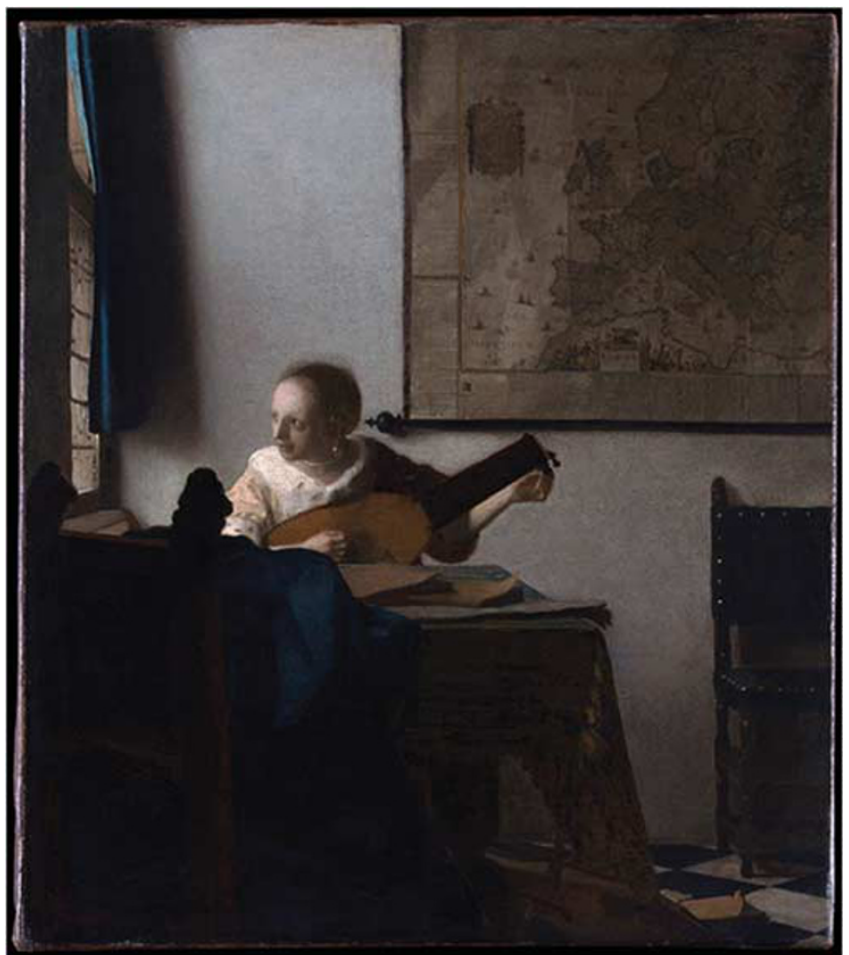

Figure 16 | Maria Vermeer?, Woman with a Lute, ca. 1674, New York, Metropolitan Museum. Copyright: Metropolitan Museum New York. This image is reproduced for the purposes of academic review (fair use). It is not covered by a CC-BY 4.0 license.
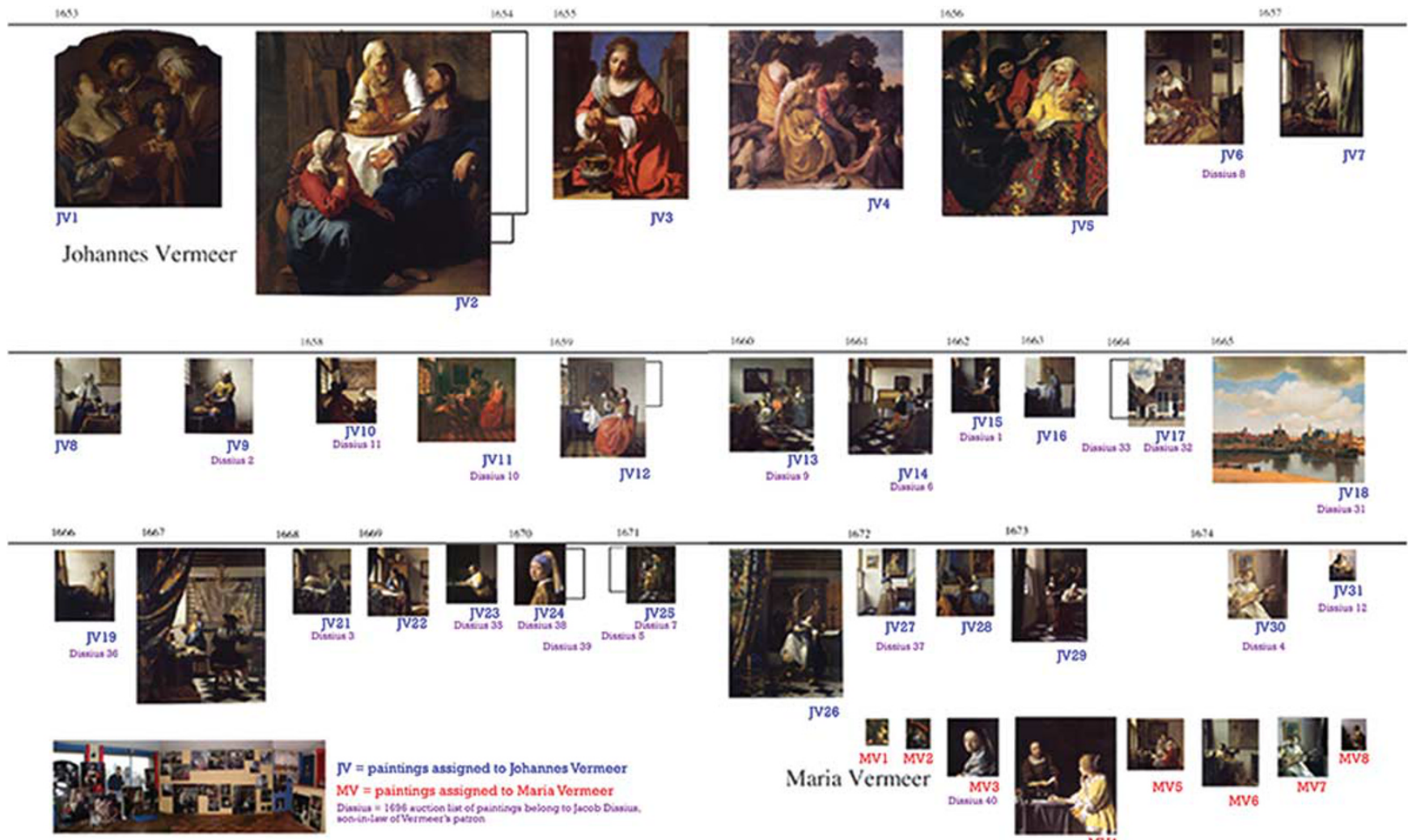

$\mathrm{V}=$ paintings assigned to Johannes Vormeer MV = paintings assigned to Maria Vermeer

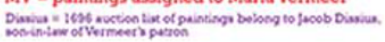
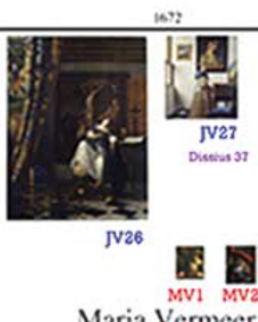

Maria Vermeer
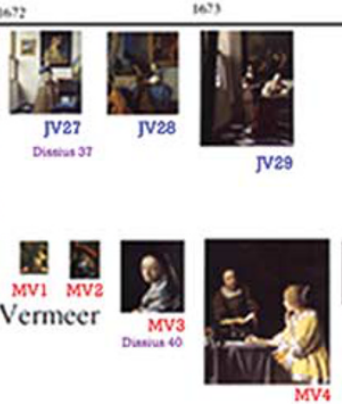
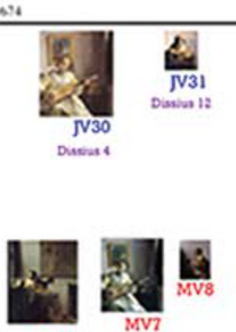

Mve

Figure 17 | Oeuvres of Johannes and Maria Vermeer (from Binstock 2009, plates 8-9). Copyright: Benjamin Binstock. Reproduced with permission of the author. 


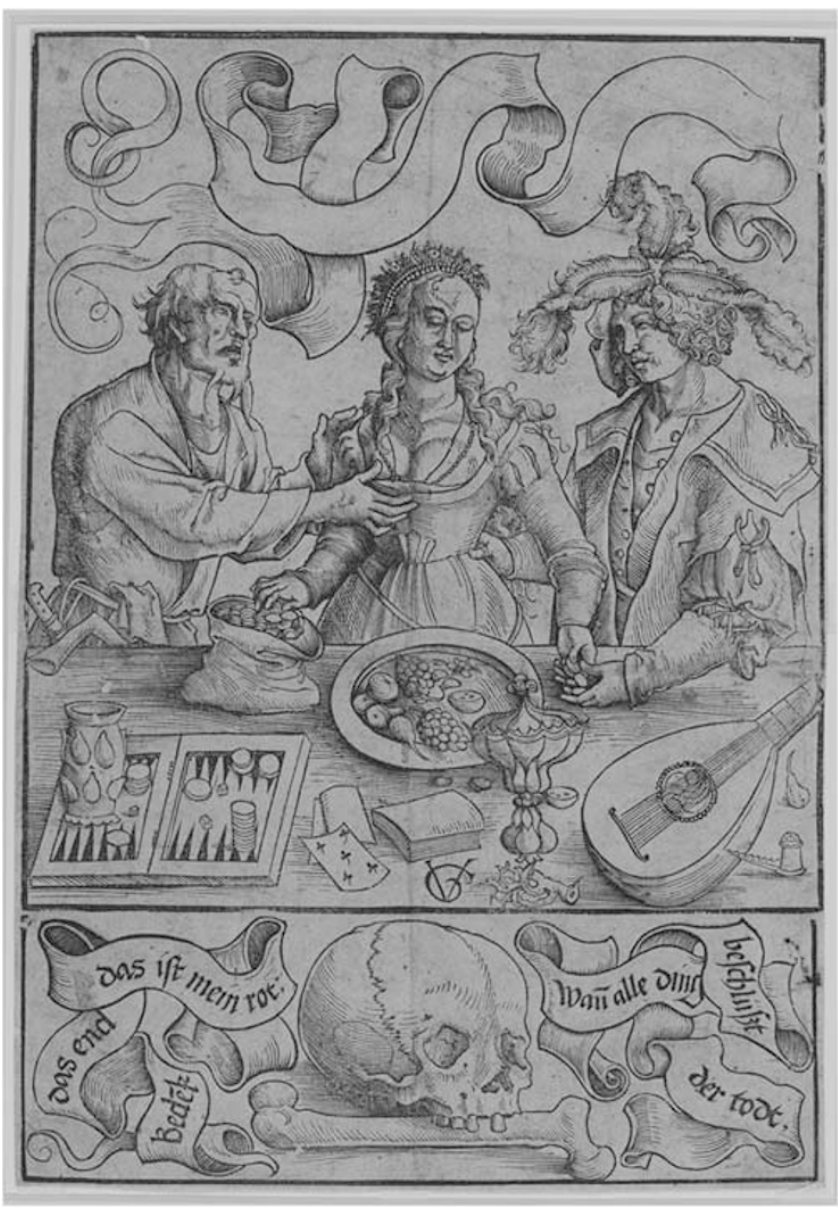

Figure 18 | Urs Graf, Unequal Love, ca. 1555?, London, British Museum. Reproduced with permission of the British Museum. This image is not covered by a CC-BY 4.0 license.

a striking contrast with Vermeer's famous Girl with a Pearl Earring. Yet the imperfect model nevertheless engages our sympathy. Woman with a Lute (Fig. 16) presents similar problems in the dark and blurry figure's head, costume, objects, and an interior that lacks a perspective scheme, technically far behind the empirically observed brilliant lighting and careful perspective of the "Delft interior" Vermeer first inaugurated in his Letter Reader (Fig. 2). Yet Woman with a Lute too offers its own charming interiority.

Previous scholars have not presented a painting-by-painting account of Vermeer's development because this is not possible with the inclusion of the misfit paintings. Conversely, the painting-by-painting chronology of Vermeer's oeuvre and his idiosyncratic development presented here are predicated upon the exclusion of the misfit paintings (Fig. 17). Previous scholars have sought to justify the misfit paintings individually in diverse ways: as forgeries, unfinished, poorly preserved, the artist having a "bad day," or as by a follower, but did not address them as a group or in a systematic manner (Gowing, 1952: 134, 146, 147; Wheelock, 1981: 112, 132; Blankert et al., 1988: 148, 171, 195-196; Arasse, 1994: 99-100; Bailey, 1995: 34; Wheelock, 1995: 144-146 and Bailey, 2001: 131, 142). Only the last explanation is plausible, particularly since these paintings emulate or combine (pastiche) elements of Vermeer's other compositions, were based on the same models, rooms, furnishing, costumes and objects, and manifest their own discernable painting-by-painting development (Fig. 17). The two examples illustrated here (Figs. 15, 16) show the same model, Vermeer's second daughter Lijsbeth, who is presented altogether differently in Vermeer's paintings based on her (JV23, 30-31). Since Vermeer did not register any official students, his follower could only have been one of his children, a possibility earlier scholars invoked, but did not pursue (Wheelock, 1981: 156).

Only Vermeer's eldest daughter Maria was old enough to be his apprentice, and in relation to his paintings using her as model she can be identified as her own model in the first two examples (MV1-2) that earlier scholars rightly compared with self-portrait studies (Gowing, 1952: 143 and Liedtke, 2008: 138). Another striking example is Young Woman at a Virginal (MV8), which early commentators assigned to Vermeer, yet most dismissed from the 1960's onward as a pastiche. When technical examination in 2004 revealed that this work and Vermeer's Lacemaker were painted on canvases cut from the same cloth, the former was rehabilitated as Vermeer's, predicated on the erroneous (and lucrative) assumption that he had no follower (Sheldon and Costaras, 2006: 96). These two paintings constituted instead a final competition between pupil and master (Fig. 17). During her short apprenticeship Maria was understandably unable to equal her father's interiors, and her effort to do so came at the increasing cost of her freedom and originality and her figures' distinct interiority (Binstock, 2009: 276-83).

After Vermeer's patron bought his last two paintings, Girl with a Guitar and Lacemaker, and both their deaths in 1675, Vermeer's widow traded Mistress and Maid and Woman with $a$ Lute (Fig. 16) as Vermeer's own paintings to a baker against a huge debt for bread (See Supplementary Appendix B, Binstock, 2009: 259-60, 267-72). ${ }^{21}$ Mistress and Maid substituted a brown curtain background for the interior that could be (and sometimes is) mistaken for unfinished, whereas the tablecloth in Woman with a Lute was left unfinished, as if by Vermeer himself, and the composition deliberately echoes that of Vermeer's Woman with a Pitcher (JV8), which the baker already owned from an earlier trade (see Supplementary Appendix B). Maria thus created a deliberate forgery. Her family apparently foresaw this possibility, and kept her apprenticeship a family secret, which would also explain the lack of other evidence of her activity, and why she did not pursue her vocation following her early marriage and her father's death. The deception of the baker was successful for the same reason that these paintings continue to be assigned to Vermeer and Young Woman at a Virginal was rehabilitated as a Vermeer: their presumed value. ${ }^{22}$

\section{Conclusion: the historical evidence}

A possible objection to what might seem a radically speculative hypothesis would be: where is the historical evidence? That is a good question. I submit that the historical evidence is plentiful and manifold, and has been clearly established by earlier scholarship, yet largely overlooked. The most important visual evidence are the paintings assigned to Vermeer (Supplementary Appendix A) as well as paintings displaying comparable approaches by Rembrandt and others. The evidence also includes written documents concerning Vermeer's life and milieu (Supplementary Appendix B). Yet despite isolated earlier proposals, our knowledge of Vermeer's circumstances has hardly been brought to bear on his paintings.

Fundamental connections remain unrecognized. These include Vermeer's house in his Little Street, the significance of his models for the subjects and meanings of his Procuress, Drunken Girl Asleep, Letter Reader and Music Lesson, his reflection on his pregnant wife as model for his Woman with a Balance and Woman in Blue, the personification in and subject of his Art of Painting, and the patron of his Allegory of Faith. 
Regarding the misfit paintings the evidence includes the unresolved debates among scholars, and the related lack of an account of Vermeer's painting-by-painting development; speculations that the misfit paintings were produced by a follower of Vermeer or one of his children and his lack of officially registered students (non-family members); the association of Woman with a Flute and Woman with a Red Hat with self-portraits; the paintings traded to the baker after Vermeer's death as opposed to those already owned by his patron; the rejection of Young Woman at a Virginal as a pastiche and its subsequent rehabilitation, and financial investments in all these paintings from Vermeer's time up to our own.

The choice before us is whether or not to address the historical evidence and to propose an explanation. The explanation offered here is that Vermeer based his interiors on rooms in his house and used his family members as models, contributing to his selfconscious development of a subjective empiricism and revolutionary modernist conception of his art. His eldest daughter Maria became his secret apprentice and elaborated in both original and limited ways on his precedent. Their achievements are necessarily understood through our own changing technical and conceptual representations of Vermeer's development, vision, and oeuvre (Fig. 17).

\section{Notes}

1 One exception is the new wife (Maureen Stapleton) of Joey's estranged banker father (EG Marshall). She is emphatically unpretentious and sensual-at one point dancing by herself she knocks over and breaks a vase, provoking Joey's outburst-and mentions that her son sells pictures painted on velvet in a Las Vegas "gallery," underscoring the triangulation in Allen's aesthetic scheme of low pleasure, value and "high art."

2 Cf. David Rakoff, "Bullets Over Broadway and Everyone Says I Love You. Adventures at a Woody Allen film festival," Tablet, December 28, 2006, http://www.tabletmag. com/jewish-arts-and-culture/1220/bullets-over-broadway-and-everyone-says-i-loveyou: "Everyone Says I Love You is a sloppy insult whose cracks and flaws are spackled over with fistfuls of money and sundry diversions in the form of real estate porn."

3 Jean Luc Godard and Federico Fellini repeatedly used their lovers as protagonist and muse, and also made films about film (mise en abyme), most explicitly in Contempt (1963) and 8 1/2 (1963), to which Allen's Stardust Memories (1980) most closely corresponds.

4 Vermeer's paintings, which are difficult to understand outside his broader development and cannot all be illustrated here, yet are easily accessible in print and on-line reproductions, are cited in relation to the painting-by-painting chronology proposed in Binstock (2009): 292-293, Supplementary appendix A, reproduced here as Supplementary appendix A (Fig. 17).

5 Swillens (1950): 69-90 plates 43-53, first sought to reconstruct Vermeer's interiors as rooms in his house, starting with his Music Lesson. Steadman (2001): 59-72, elaborated on this scheme and built a scale model of Vermeer's Music Lesson for a BBC television program. The magician Teller's film Tim's Vermeer followed the inventor Tim Jenison's reconstruction of a full-scale model of Vermeer's Music Lesson for Tim to paint with the aid of a small mirror.

6 Grijzenhout (2015) identified the scene as Vermeer's aunt's house at de Vlamingstraat 42 , a theory that has been widely embraced. However, among other problems, Vermeer was not in contact with his aunt, the specific and unusual viewpoint of his scene does not match one of de Vlamingstraat 42, and the houses behind do not correspond to those shown behind that location in Johannes Blaeu's 1649 map of Delft. All these dimensions correspond exactly to Vermeer's house at de Oude Langendijk 27.

7 Bell (2017): 35, cited James Elkins' assessment of Binstock 2009 as "the most comprehensive and detailed analysis ever published of Vermeer... full of ideas that could fundamentally change the current understanding of his paintings," yet which have not been addressed by scholars of Dutch art. Cf. also the conference on this issue at New York University's Institute for the Humanities in 2013, www.youtube.com/ watch? $\mathrm{v}=6 \mathrm{WExxEa} 3 \mathrm{pZo}$.

8 Alpers (1976): 21, 24, 37, observed that Caravaggio, Velázquez, Rembrandt and Vermeer "all produce paintings which avoid narrative action to concentrate on imitation [description]," qualities she compared with nineteenth-century French Modernist painting, an important anticipation of my thesis, although she did not address the model in the studio.

9 Binstock 2009: 56-8 observed that the seventeenth-century copy after Baburen's composition in the Rijksmuseum depot, formerly assigned to Baburen and identified as an anonymous copy since the discovery of his original in Boston, was logically by Vermeer and his still unrecognized earliest extant work (JV1). This would also explain the distinction he makes between his two representations of the painting in his Concert and Lady Seated at a Virginal (JV13, 28). Gregor Weber, "Vermeer and Van Meegeren: The Hague, Dresden and Edinburgh; Rotterdam," Burlington Magazine 152 (2010): 699 n. 15, without addressing who painted the work, dismissed as "totally absurd" Binstock's (admittedly unnecessary) proposal that the copy was Vermeer's present to his mother-in-law.

10 Gowing 1952: 87, compared Urs Graf's engraving of Unequal Love (Fig. Fig. 18), showing an old man fondling a young woman who passes coins to her handsome young lover, yet Vermeer's soldier and musician are approximately the same age. The analogy is instead relevant insofar as Catharina was Vermeer's lover, yet smilingly palms Willem's money, prefiguring the way she (and her husband) would usurp her brother's inheritance, with her mother's tacit approval.

11 Vermeer's idea was preceded by Woman Refusing Wine in London's National Gallery, which equates the Albertian picture window with a door to the room, the edge of the door's handle visible at the left. Binstock 2009: 112-116, assigned this work to Carel Fabritius in relation to the same figures (Fabritius, his wife, and brother) and motifs in his other paintings, as well as its central role in the origins of Vermeer's art and the Delft interior. Like Van Eyck, Fabritius limited his scene to the depicted space, whereas Vermeer introduced unlimited space. Roland Fleischer, "Ludolf de Jongh's The Refused Glass and Its Effect on the Art of Vermeer and De Hooch" in R Fleischer and S Scott eds, Rembrandt, Rubens, and the Art of their Time: Recent Perspectives (University Park: 1997): 250-266, assigned Woman Refusing Wine to the minor Rotterdam genre painter Ludolf de Jonghe, yet did not cite any comparable elements in De Jongh's paintings, who made no major contributions to genre painting in his period.

12 Riegl, 1988, [1899]: 169-72, identified Terborch's paintings (for example, his "Fatherly Admonition") as the furthest developed stage of Dutch painting, yet one that betrayed a sarcastic, dishonest, negative outlook. However, Vermeer represented a further development, more self-conscious, and more affirmative and direct in approach, closer to Baburen and Rembrandt. Verschaffel (2002): 291-292, observed how De Hooch opens up his scenes through doorways, archways and stairs, whereas his figures remain relatively small like those in landscape paintings: "his houses do not only feel empty and rather cold, they don't seem cozy, but they are in an almost unrealistic way open and wide or deep." Vermeer's scenes mediate between Terborch's self-consciously contained and artificial anecdotal narratives and De Hooch's more naturalistic yet meaninglessly uneventful scenes. Westermann 2003: 228, proposed that Vermeer's “signature contribution to the domestic genre... is the claim that the bourgeois interior is a fundamentally private, conversational and introspective space." That description comes close to his achievement yet still assumes an anecdotal narrative dimension, whereas Vermeer transformed the domestic interior into a modernist extension of his studio.

13 All scholars have followed Gowing 1952: 42, 78, 131, who assigned a late date to Vermeer's Woman with a Pitcher among his "pearl paintings" (Figs. 3, and 11). However, he was still uncertain in his Woman with a Pitcher of his approach to the space (the back corner) and his description of objects (the map).

14 Gowing 1952: 126 n. 84: "There might be discerned... a distant and private analogy between the man in The Music Lesson, held captive by the lady before him, and the artist himself."

15 Solomon 1983: 216-31, invoked a possible allusion to Libra. "Conscience" and "Truth" have also been invoked along with Justice, all of which share the attribute of scales, a potential problem with traditional iconography. Attention to the specific painter and image in question ("formalist iconography"), in this case, Vermeer painting his pregnant wife as his model, resolves the issue.

16 Stoichita 1997: 161-2, reviewed different accounts of Vermeer's painting and asked "are interpretive polysemy and ambiguity not the products of a failure of the discipline... or is that the painting itself lends itself to hypothetical and inadequate interpretations?" He does not offer an answer, whereas his own account of the painting focuses on the mirror, the painting on the wall, and Vermeer's painting as three different kinds of representation within a "self-aware image." The diverse interpretations, including Stoichita's, plausibly reflect the need for art historians to produce their own texts, yet these should if possible synthesize previous scholarship and reflect on their method. Vermeer's self-aware image does not involve an isolated painting, but rather his self-consciousness about his process, development and oeuvre.

17 Thanks to Ren Weschler for his observation about Catharina's "globe." Vermeer's patron owned his Woman with a Balance and Astronomer, whereas Vermeer's Woman in Blue and Geographer likely remained in his own home (see Supplementary appendix B).

18 A concrete example is the book Hultén cited as his source, the 1640 Dutch translation of Cesare Ripa, Iconologia, of Uytbeelding des Verstands [Iconology, or personifications of concepts].

19 Alpers 1983: 167-8, recognized these figures as echoes of Vermeer's model, yet identified her as Clio, whereas Vermeer's presentation of Pictura is more in keeping with Alpers' own characterization of Dutch painting as an "art of describing." Stoichita 1997, p 264, recognized the personification of Painting in the map cartouche, yet he too identified Vermeer's model as Clio, which prevented him from understanding Vermeer's self-aware meta-painting.

20 At the end of Manhattan, Allen asks himself why life is worth living and answers: "Groucho Marx, to name one thing and Willie Mays, and the second movement of 
the Jupiter Symphony, and Louie Armstrong's recording of Potato Head Blues, Swedish movies, naturally, Sentimental Education by Flaubert, Marlon Brando, Frank Sinatra, those incredible apples and pears by Cézanne, the crabs at Sam Wo's, Tracy's [the adolescent Mariel Hemingway] face," that is, art (with the exception of the last two examples of food and love) and a mix of "high" and "low," foreshadowing controversies about his future under-age daughter-lover-wife and the likely biological father of his future son!

21 Van Ruijven also appears to have bought Maria's Portrait of a Woman, corresponding to one of the three head studies on the list (nos. 38-40) of twenty-one Vermeer paintings auctioned in 1696 that were owned by his son-in-law Jacob Dissius, as opposed to twenty Vermeer paintings listed in the 1685 inventory of Van Ruijven's daughter and Dissius' wife. Montias 1989: 255, assumed the twenty-first Vermeer painting "was there all along" and omitted for some reason, yet Van Ruijven and his family would have known that Maria's Portrait of a Woman was not by Vermeer, whereas those who compiled the 1696 auction list after Dissius' death no longer recognized the difference.

22 Sotheby's auction house financed the team of scholars that rehabilitated Young Woman at a Virginal as a (Johannes) Vermeer in 2004 and then, echoing Vermeer's family in relation to the baker, sold the painting for thirty million odd dollars to the Las Vegas hotelier and collector Steve Wynn. He resold the painting in turn for approximately the same amount to a New York collector after the publication of my 2009 book, bringing us full circle to the triangulation of low pleasure, value, and "high art" in Allen's Interiors (cf. n. 1)

\section{References}

Ainsworth M et al. (1982) Art and Autoradiography. Insights into the Genesis of Paintings by Rembrandt, Van Dyck, and Vermeer. Metropolitan Museum of Art: New York.

Alpers S (1976) Describe or Narrate? A Problem in Realistic Representation. New Literary History 8, 15-41.

Alpers S (1983) The Art of Describing. Dutch Art in the Seventeenth Century. University of Chicago Press: Chicago.

Alpers S (1998) Not Bathsheba. I. The Painter and The Model. In: Adams A (ed). Rembrandt's Bathsheba Reading King David's Letter. Cambridge University Press: Cambridge: 147-58.

Arasse D (1994) Faith in Painting. trans. T. Grabar. Princeton University Press: Princeton.

Bailey M (1995) Vermeer. Phaidon Press Ltd: London.

Bailey A (2001) A View of Delft. Henry Holt \& Company: New York.

Bell J (2017) Like Leather, Like Snakes. Review of Laura Snyder, Eye of the Beholder: Johannes Vermeer, Antoni van Leeuwenhoek and the Reinvention of Seeing. London Review of Books; 39, 33-35.

Binstock (2009) Vermeer's Family Secrets: Genius, Discovery, and the Unknown Apprentice. Routledge: New York.

Blankert A et al. (1988) Vermeer. Rizzoli: New York.

Bredius A (1969) Rembrandt. The Complete Edition of the Paintings revised by Horst Gerson. Phaidon Press Ltd: New York.

Bürger W [Théophile Thoré], (1866) Van der Meer de Delft. Gazette des Beaux Arts; 21, 542-575.

Carstensen R and Putscher M (1971) Ein Bild von Vermeer in Medizinhistorischer Sicht. Deutsches Aertzteblatt-Aertzliche Mitteilungen; 68, 1-6.

Dhanens E (1980) Hubert and Jan Van Eyck. Tabard Press: New York.

Fock CW (2001) Semblance or reality? the domestic interior in seventeenthcentury Dutch genre painting. In: Westermann M (ed). Art \& Home. Dutch Interiors in the Age of Rembrandt. Zwolle, 83-101.

Gide A (1956) The Journals of André Gide 1889-1949. trans. J. O'Brien. Random House: New York.

Goldschieder L (1958) Jan Vermeer. The Paintings. Phaidon: New York.

Gowing L (1952) Vermeer. Faber: London.

Grijzenhout F (2015) Vermeer's The Little Street. A View of the Penspoort in Delft. Rijksmuseum Amsterdam: Amsterdam.

Hegel, GWF Hegel's Aesthetics. (1975) Lectures on Fine Art. trans. T. Knox. Oxford University Press: Oxford, Vol. I.

Hockney D (2006) Secret Knowledge: Rediscovering the Lost Techniques of the Old Masters. Thames and Hudson: New York.

Hollander M (2002) An Entrance for the Eyes: Space and Meaning in SeventeenthCentury Dutch Art. University of California Press: Berkeley.

Hultén K (1949) Zu Vermeers Atelierbild. Konsthistorisk Tidskrift; 18, 96-98.

Liedtke W (2008) Vermeer. Ludion Press: New York.
Malraux A (1951) 'Un artiste à jamais inconnu...' Proposition d'une nouvelle chronologie-et par là d'une nouvelle perspective-de l'oeuvre de Vermeer. Revue des Arts; 1, 195-204.

Montias JM (1989) Vermeer and his Milieu: A Web of Social History. Princeton University Press: Princeton.

Riegl A (1998 [1899]) The Group Portraiture of Holland. trans. E. Kaine. Getty Publications: Los Angeles.

Schabaker P (1972) De Matrimonio ad Morganaticum Contracto: Jan Van Eyck's 'Arnolfini' portrait reconsidered. Art Quarterly; 15, 375-398.

Sheldon L and Costaras N (2006) Johannes Vermeer's 'Young woman seated at a virginal'. Burlington Magazine; 148, 90-97.

Strauss W and van der Meulen M (1979) The Rembrandt Documents. Abaris Books: New York.

Solomon N (1983) Vermeer and the Balance of Destiny. In: Essays in Northern European Art Presented to Egbert Haverkamp-Begemann on his Sixtieth Birthday. Davaco: Doornspijk, 216-221.

Steadman P (2001) Vermeer's Camera. Uncovering the Truth Behind the Masterpieces. Oxford University Press: Oxford.

Stoichita V (1997) The Self Aware Image. An Insight into Early Modern MetaPainting. trans. A. Glasheen. Cambridge University Press: New York.

Swillens PTA (1950) Johannes Vermeer, Painter of Delft 1632-1675. Spectrum: Utrecht.

van Gogh V (1978) The Complete Letters of Vincent van Gogh. New York Graphic Society: Boston, Vol. 3 .

Verschaffel B (2002) The meanings of domesticity. The Journal of Architecture; 7, $1-6$.

Westermann M (2003) Vermeer and the Interior imagination in Alejandro Vergara, Vermeer y el interior holandés: del 19 de febrero al 18 de mayo. Museo Nacional del Prado: Madrid.

Wheelock A (1981) Jan Vermeer. Abrams: New York.

Wheelock A (1995) Vermeer \& the Art of Painting. Yale University Press: New Haven.

\section{Data availability}

Data sharing is not applicable to this article as no datasets were analysed or generated in this study.

\section{Acknowledgements}

Thanks go to Meighan Stoops, Robert Binstock, William Sommer, Bettina Brandt, Holly Haynes and Xavier Polanco for their insightful comments. This essay is dedicated to Ren Weschler.

\section{Additional information}

Supplementary Information: accompanies this paper at http://www.palgrave-journals .com/palcomms

Competing interests: The author declares that there are no competing interests.

Reprints and permission information is available at http://www.palgrave-journals.com/ $\mathrm{pal} /$ authors/rights_and_permissions.html

How to cite this article: Binstock B (2017) Interiors and interiority in Vermeer: empiricism, subjectivity, modernism. Palgrave Communications. 3.17068 doi: 10.1057/ palcomms.2017.68

Publisher's note: Springer Nature remains neutral with regard to jurisdictional claims in published maps and institutional affiliations.

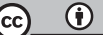

This work is licensed under a Creative Commons Attribution 4.0 International License. The images or other third party material in this article are included in the article's Creative Commons license, unless indicated otherwise in the credit line; if the material is not included under the Creative Commons license, users will need to obtain permission from the license holder to reproduce the material. To view a copy of this license, visit http://creativecommons.org/licenses/by/4.0/

(C) The Author(s) 2017 